\title{
Nutraceuticals and Exercise against Muscle Wasting during Cancer Cachexia
}

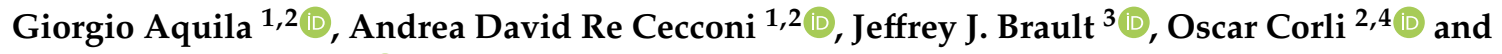 \\ Rosanna Piccirillo 1,2,*(i) \\ 1 Neuroscience Department, Mario Negri Institute for Pharmacological Research IRCCS, 20156 Milan, Italy; \\ giorgio.aquila@marionegri.it (G.A.); andrea.rececconi@marionegri.it (A.D.R.C.) \\ 2 Italian Institute for Planetary Health, IIPH, 20156 Milan, Italy; oscar.corli@marionegri.it \\ 3 Indiana Center for Musculoskeletal Health, Department of Anatomy, Cell Biology \& Physiology, \\ Indiana University School of Medicine, Indianapolis, IN 46202, USA; jebrault@iu.edu \\ 4 Oncology Department, Mario Negri Institute for Pharmacological Research IRCCS, 20156 Milan, Italy \\ * Correspondence: rosanna.piccirillo@marionegri.it; Tel.: +39-02-3901-4371
}

Received: 20 October 2020; Accepted: 18 November 2020; Published: 24 November 2020

check for updates

\begin{abstract}
Cancer cachexia (CC) is a debilitating multifactorial syndrome, involving progressive deterioration and functional impairment of skeletal muscles. It affects about $80 \%$ of patients with advanced cancer and causes premature death. No causal therapy is available against CC. In the last few decades, our understanding of the mechanisms contributing to muscle wasting during cancer has markedly increased. Both inflammation and oxidative stress (OS) alter anabolic and catabolic signaling pathways mostly culminating with muscle depletion. Several preclinical studies have emphasized the beneficial roles of several classes of nutraceuticals and modes of physical exercise, but their efficacy in CC patients remains scant. The route of nutraceutical administration is critical to increase its bioavailability and achieve the desired anti-cachexia effects. Accumulating evidence suggests that a single therapy may not be enough, and a bimodal intervention (nutraceuticals plus exercise) may be a more effective treatment for $\mathrm{CC}$. This review focuses on the current state of the field on the role of inflammation and $\mathrm{OS}$ in the pathogenesis of muscle atrophy during $\mathrm{CC}$, and how nutraceuticals and physical activity may act synergistically to limit muscle wasting and dysfunction.
\end{abstract}

Keywords: cancer cachexia; muscle wasting; muscle atrophy; lifestyle interventions; nutraceutical; exercise; myokine; nutrition; bimodal approach

\section{Introduction}

\section{Definition and Classification of Patients with Cancer Cachexia}

Cancer-induced cachexia (CC), a debilitating syndrome characterized by progressive loss of skeletal muscle mass and function (with or without fat loss), affects about $80 \%$ of patients with advanced cancer [1,2]. Besides peripheral muscle atrophy, patients with CC also experience cardiac atrophy, remodeling, and dysfunction that can lead to heart failure [3,4], as well as diaphragm atrophy that can cause respiratory collapse [5]. Both conditions contribute to poor quality of life and reduced survival in $30-40 \%$ of cases. CC is still an unmet medical problem.

Three progressive stages of CC have been classified in [2], based on disease severity: pre-cachexia, cachexia, and refractory cachexia. The goal of this classification is to identify patients who are likely to benefit from early interventions and to limit and/or reverse body weight and muscle loss. Pre-cachexia involves only metabolic changes, such as impaired glucose tolerance, causing negligible body weight loss (BWL). Cachexia is defined by BWL $>5 \%$ in six months or BWL $>2 \%$ and 
body mass index $(\mathrm{BMI})<20 \mathrm{~kg} / \mathrm{m}^{2}$ or muscle depletion and more severe metabolic derangements. Refractory cachexia is distinguished by unresponsiveness to cancer treatment where its management is no longer possible [2]. Life expectancy decreases through the various stages of CC, from 6-9 months for patients with pre-cachexia to less than 3 months in individuals with refractory cachexia. Human body composition (i.e., fat and muscle content) are usually estimated by computed tomography or more indirectly by bioelectrical impedance analysis [6]. Additional diagnostic parameters, such as anemia, anorexia, loss of muscle strength [7], and possible genetic propensities, can further complicate the classification and the progression of cachectic cancer patients.

In 2017, among the guidelines described by the European Society for Clinical Nutrition and Metabolism (ESPEN) for nutritional care in cancer patients (reviewed in [8]), the following key recommendation was highlighted: "Use nutritional intervention with individualized plans, including care focused on increasing nutritional intake, decreasing inflammation and hypermetabolic stress, and increasing physical activity". This "call-to-action" by ESPEN experts emphasized the importance of both nutritional interventions-including food-derived products (i.e., nutraceutical compounds) - and exercise to counteract CC. While the beneficial effects of physical activity on survival [9], as well as the anticancer effects of nutraceuticals are known [10], whether and how physical activity and nutraceuticals together prevent or circumvent CC is still unclear. According to the American Society of Clinical Oncology (ASCO) guidelines, "outside the context of a clinical trial, no recommendation can be made for other interventions, such as exercise and nutritional supplements, for the management of CC" [11].

Our main goal here is to review the role of nutrition, nutraceuticals, and exercise in the treatment of muscle wasting associated with cancer. First, we discuss the pathogenic mechanisms linked to muscle atrophy during CC, emphasizing the contributing role of oxidative stress (OS). Next, we highlight how changes in nutritional habits, nutraceutical interventions, and physical activity can help to preserve muscle mass and function, providing evidence from preclinical models and cachectic patients. Last, we look ahead to future investigations in patients, such as the evaluation of their redox status, to intervene effectively to improve their quality of life.

\section{Pathogenesis of Cancer Cachexia: Inflammation and Oxidative Stress}

\subsection{Mechanisms of Muscle Wasting During Cancer Cachexia}

Cancer cachexia is accompanied by an increase in systemic inflammation [12]. The inflammation causes systemic dysmetabolism in the host where the tumor growth deprives the body of amino acids, nutrients, and energy fuels, at the expense of organs such as skeletal muscles [13]. Muscles are comprised of a combination of glycolytic myofibers, mainly relying on glucose and glycolytic metabolism, which are able to exert strong force in a short time, and oxidative fibers that are more resistant to fatigue because of a richer concentration of ATP-producing organelles, such as mitochondria, and greater vascularization for enhanced oxygen delivery. Oxidative fibers are more resistant to atrophy subsequent to fasting or cancer-related inflammation, but they undergo atrophy more rapidly due to disuse [14]. It is estimated that muscle catabolism increases by $40-60 \%$ in humans during cachexia [15]. Most tumors are highly metabolically active and dependent on glucose and glutamine for their growth [13]. Therefore, tumor growth deprives the muscles of nutrients and causes a shift in muscle metabolism, which, converting its structural proteins into amino acids, in turn fuels the liver to produce glucose (gluconeogenesis) as a survival plan and to mount the hepatic acute phase response to inflammation further consuming energy.

Pro-inflammatory molecules, such as interleukin-6 (IL-6), tumor necrosis factor alpha (TNF $\alpha$ ), IL-1, and interferon- $\gamma$, derived from the immune system or from the tumor itself and glucocorticoids, are increased in plasma of rodents and patients with different cancers [16]. Their induction is not sufficient to induce cachexia, as some individuals or animal models have increased levels of these inflammatory molecules and do not present muscle wasting $[17,18]$. Further, at the cellular level, 
myotubes in vitro exposed to high concentrations of these cytokines do not consistently present increased proteolysis [19], confirming that other factors alone or in combination with inflammatory cytokines are more likely to cause muscle wasting directly [20].

In clinical trials, the neutralization of circulating IL- 6 or TNF $\alpha$ have not proven useful to counteract CC, indicating that other factors are involved in cachexia [21,22]. Indeed, novel molecules have recently been identified as triggers of muscle wasting during cancer, at least at the preclinical level, such as leukemia inhibitory factor (LIF) [23], TNF-related weak inducer of apoptosis (TWEAK) [24], the negative regulator of muscle mass myostatin [25,26], High Mobility Group Box 1 (HMGB1) [13], tumor-derived parathyroid hormone-related protein [27], growth differentiation factor 15 (GDF-15) [28], and microRNAs from the tumor itself [29-31]. Regrettably, the concomitant inhibition of many of them is unpractical at this time.

In 2004, a set of genes were identified that were differently expressed in skeletal muscles from rodents undergoing atrophy due to a variety of conditions (disuse, uremia, cancer, and diabetes); these genes were defined as "atrogenes" [32]. Atrogenes comprise upregulated genes encoding for many subunits of the $26 \mathrm{~S}$ proteasome, ubiquitin ligases such as atrogin- 1 and Muscle RING-finger protein-1 (MuRF1), and ubiquitin-all indicative of the enhanced protein degradation common to all atrophying muscles analyzed. Atrogenes that were reduced include certain growth-associated proteins such as the peroxisome proliferator-activated receptor $\gamma$ coactivator $1 \alpha(\mathrm{PGC} 1 \alpha)$ and JunB.

In skeletal muscles, transcription factors such as forkhead box O3 (FoxO3), also belonging to the family of atrogenes, nuclear factor kappa-light-chain-enhancer of activated B cells (NF-kB), signal transducer and activator of transcription 3 (STAT3) are also all activated by tumor-related inflammation. They enhance the expression of genes encoding molecules, such as atrogin- 1 and MuRF1, that promote the proteasomal degradation of muscle proteins, leading to atrophy [33-36]. In detail, MuRF1 (also known as TRIM63) is responsible for the degradation of myosin heavy chain [37] and other components of the thick but not the thin filaments [38]. Instead, atrogin-1 (known also as MAFbx or Fbxo32) ubiquitinates and so promotes the proteasomal digestion of MyoD (a transcription factor crucial for muscle differentiation) [39]. Both atrogin-1 and MuRF1 are induced in cachectic muscles of cancer-bearing rodents [32] and in the muscles of cancer patients even before muscle depletion [40]. Other less studied ubiquitin ligases involved in the accelerated proteolysis typical of CC include TNF receptor-associated factor 6 (TRAF6) [41-43], the ubiquitin ligase E3 $\alpha$-II [44], and muscle ubiquitin ligase of Skp, Cullin, F-box (SCF) containing complex in atrophy-1 (MUSA1) [45].

During muscle wasting, FoxO3 induces a transcriptional response that not only promotes the proteasomal degradation of proteins but also coordinately induces genes involved in the degradation of proteins and organelles through the autophagic pathway [46,47]. Destruction of proteins from the sarcomere contributes to loss of muscle strength, while removal of ATP-producing organelles, such as mitochondria by autophagy (mitophagy), contributes to the lower resistance to fatigue typical of cancer patients. Another player coordinately involved in diverting proteins to proteasomes and lysosomes in skeletal muscle is the p97/Valosin-containing protein (VCP) ATPase complex [48,49]. Unexpectedly, its expression is not under the control of FoxO3 [50] but another transcription factor named Pax4 [51].

The main signaling pathway leading to increased protein synthesis involves AKT/phosphatidylinositol-3-kinase (PI3K) and results in the activation of eukaryotic translation initiation factor 4E-binding protein (4E-BP1) and ribosomal protein S6 kinase beta 1 (S6K1), which, together, enhance protein translation. Major activators of this pathway are insulin-like growth factor 1 (IGF1) and insulin. Conversely, the growth-promoting transcription factor JunB exerts its hypertrophic effects in an AKT-independent way, reducing atrogene expression overall [52]. These pathways are depressed in muscles undergoing cancer cachexia [53,54]. As a consequence, not only is protein degradation increased but protein synthesis too seems to be attenuated, further exacerbating protein loss, as in murine colon adenocarcinoma 16 (MAC16)-bearing rodents [55], Lewis Lung carcinoma (LLC)-carrying mice [56], and in cancer patients [57]. Interestingly, atrogin-1 also restrains protein 
synthesis by promoting the degradation of the elongation factor eIF3-f [58], further aggravating muscle loss during wasting. Similarly, by ubiquitinating and degrading the insulin receptor substrate 1 (IRS1) that is an important signaling interactor of insulin/IGF1 receptor, the ubiquitin ligase Fbxo40 is involved in restraining IGF1-mediated protein synthesis [59].

Muscle wasting due to net protein loss, with no reduction in the number of myofibers (i.e., hypoplasia), is reversible. Removal of the primary tumor before appearance of metastases-at least in the early stages (i.e., before cachexia becomes refractory)—is sufficient to reverse the initial muscle atrophy in mice [60] and in rats [61]. Sometimes removal of the primary tumor is impossible, and the patient goes through progression of disease and development of metastases. Metastasis and cachexia should be thought of in parallel, highlighting the overlapping pathways between them [62]. Inflammation and metabolic dysregulation are key factors in the pathophysiology of cachexia and at the same time of metastases and tumor progression [63]. In cancer patients as in old individuals, a complicating factor has been reported: anabolic resistance. This may explain the third stage of the disease, refractory cachexia. Molecular adaptations to tumor burden in skeletal muscles result in refractoriness to the anabolic signaling pathways (i.e., AKT, mammalian target of rapamycin (mTOR), JunB) usually activated by nutrition and growth-stimulating exercise (anaerobic physical activity). This has also been observed in preclinical animal models [64] as well as in advanced cancer patients suffering from cachexia [65] and currently indicates a point of no return in CC management.

Strategies aimed at preserving both contractile proteins and mitochondria should be pursued to preserve muscle strength and alleviate muscle weakness in patients at the same time. Activation of PGC1 $\alpha$ through aerobic exercise could be useful to exert both these protective effects. PGC1 $\alpha$ is the key transcriptional co-activator promoting mitochondrial biogenesis [66] and an antioxidant defense (mainly increasing nuclear factor erythroid 2-related factor 2 or Nrf-2) [67]. At the same time, it antagonizes the DNA binding of FoxO3, impairing atrogene transcription, avoiding the concomitant increase in proteasomal and autophagy-mediated proteolysis [68], and ultimately protecting mice from muscle atrophy [69]. PGC1 $\alpha$ also controls the expression of muscle-secreted factors (i.e., myokines), such as irisin or musclin [70,71]. We recently found the PGC1 $\alpha$-musclin axis was depressed in atrophying muscles during cancer [70] and that restoring the expression only of musclin in cachectic muscles of cancer-bearing mice protects them from fiber atrophy [70].

\subsection{Link between Oxidative Stress and Muscle Wasting}

To further complicate the known transcriptional mechanisms of protein loss, OS is thought to be a key contributor in the deleterious process of muscle wasting in cancer or other chronic diseases. A commonly accepted definition of OS is "an imbalance between oxidants and antioxidants in favor of the oxidants, leading to disruption of redox signaling and/or molecular damage" [72]. Oxidants are those substances that can generate reactive oxygen species (ROS) or induce OS, while antioxidants include substances that when at low concentrations with respect to a certain substrate are enough to delay or prevent its oxidation [73]. ROS, comprising both free radicals, such as superoxide anion $\left(\mathrm{O}_{2}{ }^{\bullet-}\right)$, and nonradicals, such as hydrogen peroxide $\left(\mathrm{H}_{2} \mathrm{O}_{2}\right)$, are part of a bigger family referred to as reactive species that encompasses reactive nitrogen and reactive chlorine species. Since $\mathrm{O}_{2}{ }^{\bullet-}$ is the primary free radical that gives rise to major cell-damaging reactants (e.g., hydroxyl free radical, $\mathrm{OH}^{\bullet}$ ) [72], most of this review will refer to ROS in CC.

In mammalian cells, $\mathrm{O}_{2}{ }^{\bullet-}$ originates from NADPH oxidases (NOX), the mitochondrial electron-transport chain, xanthine oxidases, cyclooxygenases and lipoxygenases, uncoupled nitric oxide synthases (NOS), and cytochrome P450s. By contrast, the antioxidant defense depends on enzymes such as superoxide dismutase (SOD), catalase, and glutathione peroxidase (GPx) or non-enzymatic molecules such as vitamin C, vitamin E, glutathione, and beta-carotene. Transferrin, ceruloplasmin, and albumin also act as indirect antioxidants by buffering metal ions such as iron and copper, preventing them from reacting with $\mathrm{H}_{2} \mathrm{O}_{2}$ and ultimately avoiding the generation of the toxic $\mathrm{OH}^{\bullet}$ [74]. The less recognized protein metallothioneins exert similar buffering and protective role [75]. 
Among the atrogenes originally identified [32], activating transcription factor 4 (ATF4) [76] and nuclear factor, erythroid derived 2, like 2 (Nfe212, also named Nrf-2) [77], are transcription factors that promote the expression of genes controlled by antioxidant response elements. They were both induced 3-4-fold in all four states tested, including muscles atrophying because of cancer [32]. This indicates that inducing both the atrogenes ATF4 and Nfe212 are part of a means to regulate ROS. Notably, preventing FoxO3 action results in loss of induction of at least ATF4 during atrophy [78]. On the other hand, the notion that enhanced OS contributes to muscle wasting is also supported by SOD1 inactivating mutations that lead, among other effects, to muscle depletion in animal models and patients with amyotrophic lateral sclerosis (ALS) $[79,80]$. When a cachexia-inducing tumor such as LLC was injected in SOD1 knock out (KO) mice, the cancer-induced muscle loss and dysfunction were not further exacerbated by OS, while a quarter of the mice died earlier than LLC-bearing WT mice [81]. How SOD1 depletion affects premature death in LLC-carrying mice is still not clear.

Even more convincing was the drastic induction of the expression of metallothioneins in all atrophy conditions tested [32]: they were among the most induced atrogenes in atrophying muscles (3- to 20-fold, depending on the isoform). Metallothioneins are low-molecular-weight cysteine-rich zinc-binding proteins that are induced by heavy metals, glucocorticoids, and OS; they can protect cells against DNA damage from ROS and detoxify cells from heavy metals [75]. It was recently reported that ablation of metallothioneins 1 and 2 in myotubes and in adult muscles preserves mass and strength in glucocorticoid-induced atrophy, making the beneficial role of their induction during atrophy debatable [82]. To further complicate the picture is the fact that heavy metals, such as zinc, are increased at the onset of muscle wasting during cancer, at least in preclinical animal models [83].

Despite the concomitant activation of these detoxifying systems (ATF4, Nfe212, metallothioneins) in emaciated muscles, OS seems not to be resolved in muscles during wasting in general and during CC in particular. Concomitant induction of prooxidant species and antioxidant players, ultimately resulting in increased OS, has been seen in muscles of AH-130 hepatoma-bearing rats and C26 colon adenocarcinoma-carrying mice [84,85]. In transforming growth factor beta (TGF- $\beta$ )- [86], $\mathrm{TNF} \alpha$-induced muscle atrophy [87], or even in animal models of CC [88] or genetically modified animals displaying muscle wasting (i.e., skeletal muscle-specific transforming growth factor- $\beta$ activated kinase 1 or Tak1-KO mice [89]), increased ROS levels divert muscle fibers towards enhanced protein degradation, leading to muscle loss [90]. Notably, angiotensin II has been shown to increase ROS-induced proteasomal pathway in muscles of MAC16-bearing mice [91], as in other diseases associated with muscle wasting [92]. Among the possible molecular mechanisms, it seems that increased circulating TNF $\alpha$ typical of CC can trigger muscle OS and increase NOS, impairing the expression and DNA binding ability of myosin creatinine phosphokinase, reducing the related expression of contractile proteins, ultimately causing atrophy [88]. In addition, the reduction in expression and activity of antioxidant enzymes, such as GPx, despite the induced SOD1 and the reduced NOX, ultimately results in the increase in superoxide content, contributing to CC in muscles of MAC16-bearing mice [93] and seemingly in patients suffering from gastric or esophageal or pancreatic cancers [94].

Molecules signaling towards muscle wasting that can sense intracellular ROS are NF-kB [95], further linking inflammation with OS, PI3K/AKT/mTOR [96] and FoxO3 [97]. A summarized scheme showing how OS impacts on muscle anabolic and catabolic pathways is shown in Figure 1. During CC, ROS can promote muscle protein degradation through the ubiquitin proteasome system (UPS) stimulation [90], but also augmented nitrosative stress that occurs subsequently to uncontrolled nitric oxide accumulation plays a role in the hypercatabolism during CC [98]. In particular, protein carbonylation-measured by total levels of carbonyl group formation and both hydroxy-4-nonenal-(HNE) and malondialdehyde (MDA)-protein adducts—as well as protein tyrosine nitration are aberrantly high in muscles of cancer-bearing rats with late-stage cachexia, but levels of antioxidant enzymes such as Mn-SOD, catalase, and heme oxygenase-1 (i.e., HO-1) did not change in muscles [98]. To test the effects of antioxidants such as $\alpha$-lipoic acid, $\mathrm{N}$-acetylcysteine (NAC), and amifostine, ROS levels and antioxidant enzymes, such as GPx and SOD, have been measured 
in blood of patients with cachexia and ROS found to be increased, while GPx and SOD decreased, overall resulting in OS increase [99].

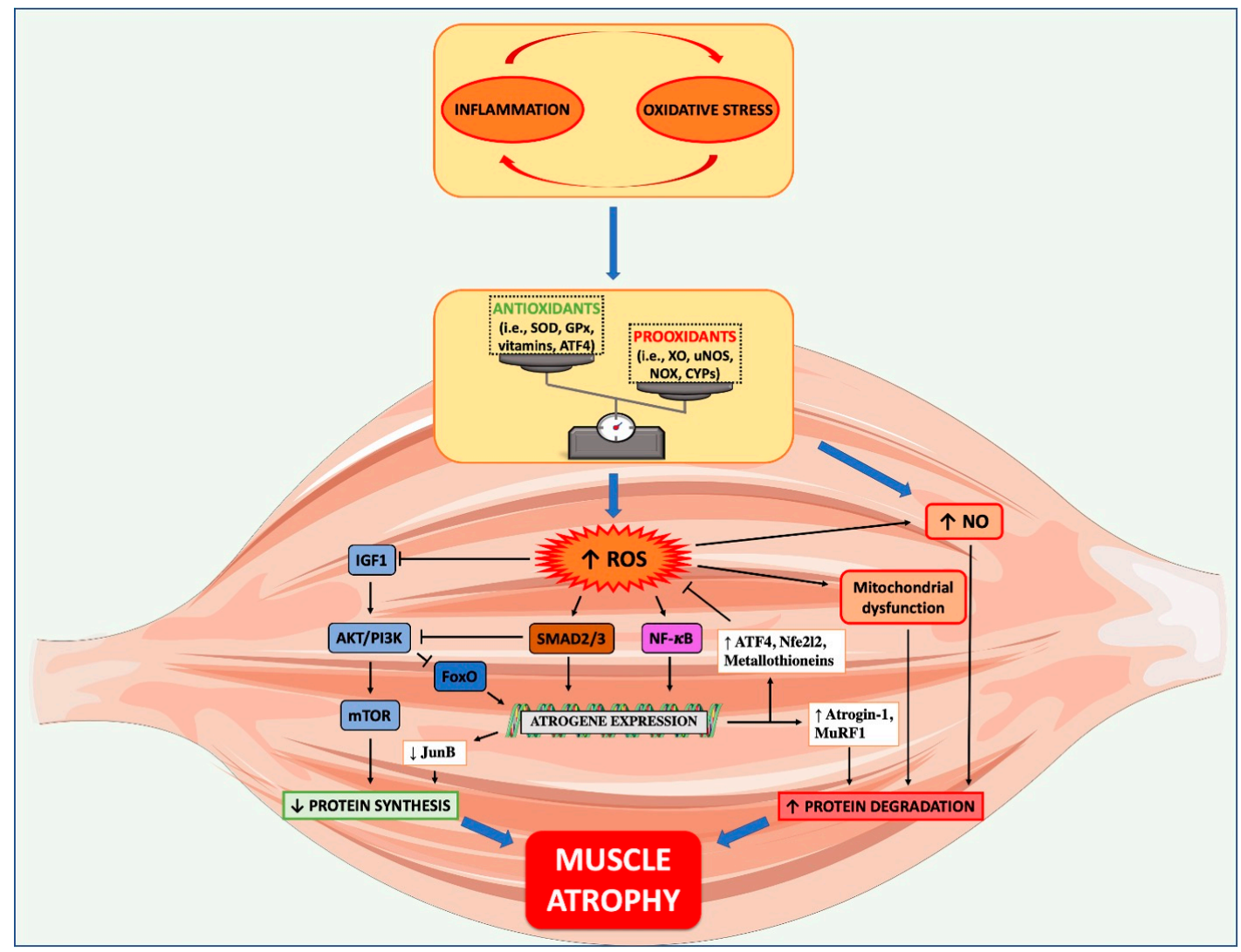

Figure 1. Role of oxidative stress in muscle wasting during cancer cachexia. The crosstalk between increased inflammation and oxidative stress, occurring during cancer cachexia (CC), can drive in muscles an imbalance between antioxidant and pro-oxidant systems, favoring the generation of different sources of reactive oxygen species (ROS). During CC, ROS can reduce protein synthesis, by inhibiting IGF1/PI3K/mTOR pathway, and increase protein degradation, by stimulating pro-atrophic pathways such as FoxO3, SMAD2/3, and NF- $\mathrm{B}$. The latter promotes the ubiquitin proteasome system activation (atrogin-1 and MuRF1) that, along with ROS-mediated nitric oxide (NO) accumulation and mitochondrial dysfunction, facilitates the hypercatabolism typical of CC. Despite the concomitant activation of detoxifying systems (ATF4, Nfe212, metallothioneins), OS seems not to be resolved in muscles during CC.

The scenario is complicated even more by the ability of inflammatory molecules that are increased in the blood during CC to bypass the blood-brain barrier and promote neuroinflammation [100-103]. This in turn stimulates hypothalamic serotonergic activity and promotes tryptophan degradation into free radicals via the kynurenine pathway, thus favoring OS [104]. Overall, this mechanism seems to contribute to loss of appetite and then anorexia during CC [105]. Notably, IL-1 appears to be more potent in inducing anorexia than IL-6 [106]. A bed-ridden state and loss of appetite further aggravates the muscle loss of cancer patients, setting up a vicious cycle that is hard to break so as ultimately to preserve the individual's health. These aspects are consistent with the symptomatologic picture of CC patients where asthenia and anorexia are often pronounced. Overcoming this central brake to food intake in these patients is another challenge in the development of efficient anti-cachexia therapies.

Finally, it seems that inflammation and OS are intimately connected, and one can exaggerate the other (Figure 1), giving rise to various disease states [74]. Consequently, therapies based only on anti-inflammatory or antioxidant compounds are likely to fail. Ways to counteract and/or limit OS have been tested to restrain muscle wasting during cancer progression. Some nutraceuticals listed further on 
are especially useful to reach this aim and keep muscles healthy in cancer patients, whose metabolism is widely dysregulated by cancer progression.

\section{From Nutrition to Nutraceuticals against Cancer Cachexia}

\subsection{Cachexia Cannot Be Fully Reversed by Nutritional Supplementation}

"Let food be your medicine and medicine be your food": this was the aphorism that Hippocrates, the Greek father of medicine, formulated over 2000 years ago to sum the idea of using nutrition to promote good health and to treat pathologic conditions. Malnutrition is a common complication in cancer patients and a significant contributor to morbidity and mortality in malignancies $[107,108]$. How to manage malnutrition in cancer patients is still controversial. While some studies support personalized nutrition and programs of nutritional counseling for cancer patients [108-111], others report that increasing nutritional intake is not enough to counteract CC $[2,7,108]$ and reduce mortality or secondary cancers [112-115]. On the other hand, CC patients subjected to aggressive refeeding can develop an overfeeding reaction during the first 2-3 weeks [116]. This can be lethal and consists of severe electrolyte and fluid shifts, with aberrant glucose metabolism, hypophosphatemia, hypomagnesaemia, and hypokalemia, due to metabolic derangements [117]. Introduction of calories must be slow and progressive ( $20 \mathrm{kcal} / \mathrm{kg}$ per day initially) in CC patients, under close medical control to avoid undesirable and possibly dangerous reactions.

The cachexia that cancer patients often develop is a multifactorial syndrome characterized by loss of appetite and weight, leading to fatigue and functional impairment, increased treatment-related toxicity, poor quality of life, and reduced survival [11]. Low food intake is an important component of weight loss, but an aberrant metabolism, amply described in this review, is also implicated in its genesis [11]. Symptoms such as pain, dysgeusia, nausea, constipation, and depression can also contribute appreciably to poor food intake [118]. Unlike starvation, that is linked to environmental nutrient scarcity or voluntary choice not to feed and leads to an increased fat and protein catabolism, cachexia is characterized by an appetite suppression and reduced ability to feed, with strong negative metabolism of all fat, protein, and basal metabolic rate [119]. While starvation induces a similar reduction in both energy intake and expenditure, cachexia promotes decreased energy intake and increased expenditure. Overall, cachexia causes metabolic adaptations that diverge from both starvation and malnutrition and depletes the body energy stores, ultimately leading to death [119]. For these reasons, cachexia cannot be fully reversed by nutritional supplementation. Consistently, even phase III clinical trials testing hormone-based therapies (i.e., anamorelin) in the attempt to increase appetite in patients afflicted by non-small-cell lung cancer cachexia failed to ultimately preserve their muscle strength (ClinicalTrials.gov Identifiers: NCT01387269 and NCT01387282).

The usual diet, without attention to the quantity and quality of the food taken, fails to prevent the onset and development of CC. The dietary advice had to specify the type and amount of food, the eating frequency, the calories and protein amounts to achieve daily, and the dietary restrictions. Nevertheless, a recent study on an animal model [120] focused on the distinct metabolic substrates evaluating the impact of two types of nutrients, sugar and lipids. The authors compared the influence of oral intake of glucose $(0,10,50 \%$ solutions) and $2 \%$ lauric acid, a medium-chain fatty acid (MCFA), on skeletal muscle atrophy and tumor growth. Additional glucose intake had no effect on muscle loss but promoted tumor growth. MCFA prevented the loss of skeletal muscle mass and suppressed tumor growth. The combination of glucose and MCFA together was better at protecting against tumor-induced muscle mass loss but allowed the tumor to grow further than with MCFA alone. Therefore, the combined intake of these different macronutrients may help alleviate CC and is expected to be proposed for future clinical applications.

A further contribution to assessing the role of diet on the mechanisms of OS involved in the genesis and progression of cancer cachexia comes from a recent review [121], which highlights how some dietary components reduce or exacerbate inflammation and OS. High glycemic load determines 
hyperinsulinemia, which is linked to cell proliferation in various cancers [122]. Excessive animal protein intake increases ROS production and promotes antioxidant instability. Similarly, a high-fat diet promotes the production of ROS, along with the elevation of $\mathrm{TNF} \alpha$, resulting in chronic inflammation [123]. A common denominator of these observations is the excess intake of the nutrients.

Selected dietary components can affect cancer development. The protective effect of several vitamins in prostate cancer has been widely demonstrated in clinical trials and laboratory experiments [124]. Vitamin $\mathrm{E}$ has been reported to reduce the oxidative damage and help stabilize disease progression, the clinical picture, and median progression-free survival [125]. Vitamins A and $\mathrm{D}$ too give a positive response in prostate cancer. Among minerals, usually absorbed from drinking water and food, selenium in particular has antioxidant properties, leading to a reduction in ROS [126]. The authors conclude that a diet high in animal proteins and carbohydrates and excessive fat consumption can generate ROS, resulting in OS with all the consequences on tumor development and cachexia. The final dietary advice includes reducing carbohydrates, consuming moderate amounts of calories, reducing overcooked meats, saturated and total fats, replacing refined carbohydrates with whole grains, and increasing vegetable and fruit intake.

The general role of nutrition in CC patients has been the topic of several recent reviews. A 2012 meta-analysis on dietary advice to adult cancer patients indicated that oral nutritional interventions did not affect mortality but could improve the quality of life [127]. In a 2014 systematic review focused on dietary counseling in patients with advanced cancer and cachexia, the authors found that the moderate quality of the studies included did not allow any firm conclusion on the effectiveness of nutritional interventions [128]. Instead, a more recent meta-analysis from 2018 [129] stated that dietary counseling and/or oral nutritional supplements were associated with improved body weight in cancer patients receiving chemo/radiotherapy.

Finally, in 2020 the ASCO published a systematic review from which some recommendations were made on the clinical management of cachexia in adults patients with advanced cancer [11]. The panel of experts moderately recommended in favor of dietary counseling, to produce some benefits that need to be complemented by medications or other strategies.

\subsection{Nutraceuticals}

In tackling the nutrition-related issues in CC, pre-clinical and clinical research is shifting towards promising nutraceutical-based schemes. The neologism "nutraceutical" was coined in 1989 by joining the words "nutrition" and "pharmaceutical" by Dr. Stephen De Felice to refer to substances that are "a food (or part of a food) that provides medical or health benefits, including the prevention and/or treatment of a disease" [130]. Nutraceuticals include "functional foods", which are whole, or "fortified, enriched and enhanced" foods that supply the required amount of essential nutrients (e.g., vitamins, fats, and minerals) to confer health benefits and, most importantly, "dietary supplements" [131]. These latter, as indicated by the Food and Drug Administration (FDA) agency, are "products taken by mouth (as pills, capsules, tablets, or liquid) that contain a dietary ingredient". Dietary ingredients include vitamins, minerals, herbs, or botanicals, as well as other substances that can be used to supplement the diet.

Nutraceuticals, particularly dietary supplements, cannot replace conventional medicine since, accordingly to the FDA agency, they "are not intended to treat, diagnose, cure, or alleviate the effects of diseases". Nonetheless, some of them provide a promising source of compounds helpful in reducing the risk and/or progression of some widespread diseases, such as atherosclerosis [132] and cancer [133]. In recent years, several classes of food- and plant-derived nutraceuticals have also shown the potential for limiting CC, and thus for improving patients' quality of life. Those for which the major experimental evidence is available are discussed below, and their way of action at the molecular level is summarized in Figure 2. 


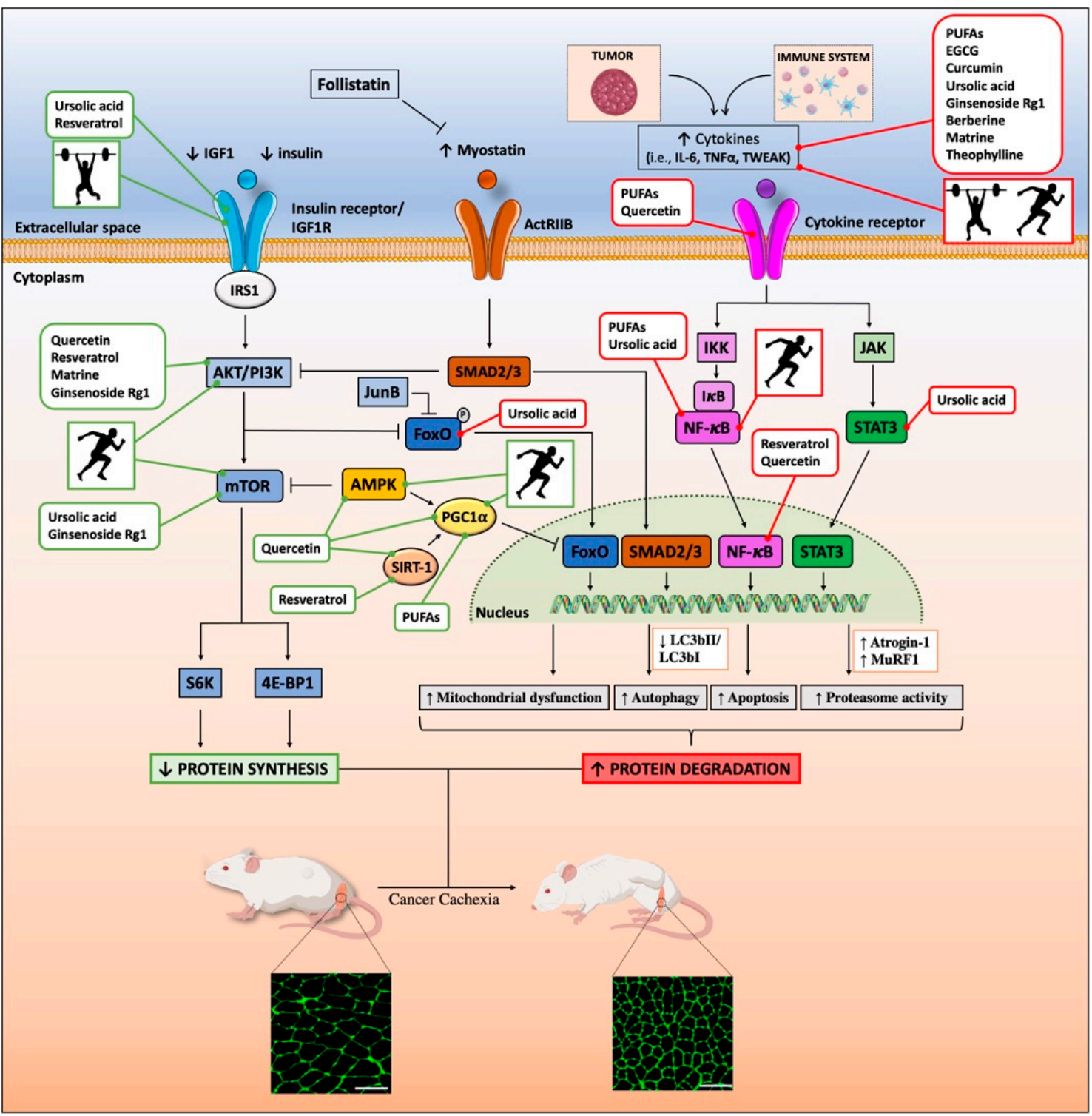

Figure 2. Beneficial effects of nutraceuticals and physical activity against muscle atrophy during cancer cachexia. Graphical representation of the main findings of in vitro and in vivo studies, which have investigated the mechanisms underlying the benefits of the nutraceuticals and physical exercise against muscle wasting during cancer cachexia. In brief, nutraceuticals and physical exercise can favor protein synthesis in muscle by inducing both anabolic (i.e., IGF-1/AKT/mTOR) and anti-catabolic pathways (i.e., AMP-activated protein kinase (AMPK), SIRT1, and PGC1 $\alpha$ ) (in green). On the other hand, they can limit protein degradation by inhibiting pro-catabolic pathways (i.e., FoxO3, SMAD2/3, and NF- $\mathrm{B}$ ) (in red), thus limiting the expression of genes involved in mitochondrial dysfunction, autophagy, apoptosis, proteasomal degradation, and inflammation. The running man and the weightlifter represent "endurance/aerobic" and "resistance/strength" trainings, respectively. A transversal section of a tibialis anterior stained for wheat germ agglutinin (WGA) and coming from a healthy and a colon adenocarcinoma 26 (C26)-bearing mouse are shown. Scale bar: $100 \mu \mathrm{m}$.

\subsubsection{Omega-3 Fatty Acids}

Omega-3 (n-3) fatty acids are polyunsaturated fatty acids (PUFAs) that contain the first carbon-carbon double bond in the third position from the omega (methyl) end of the molecule. PUFAs, and in particular eicosapentaenoic acid (EPA) and docosahexaenoic acid (DHA), are mainly sourced from marine fish and fish oil. They offer various health benefits, most likely due to the 
resolution of inflammation, throughout the production of resolving lipid mediators, such as resolvins, maresins, or protectins (reviewed in [134]). Both EPA and DHA partly restrain inflammation by limiting the production of highly inflammatory eicosanoids, such as prostaglandins and leukotrienes, derived from the n-6 fatty acid arachidonic acid (AA) [135]. PUFAs also interfere with NF-kB-mediated inflammation through the inhibition of Toll-like receptor 4 (TLR4) [136] and activation of peroxisome proliferator-activated receptor gamma (PPAR $\gamma$ ) signaling [137].

Other mechanisms include PUFA binding with G-protein-coupled receptor 120 (GPR120) [138], leading to strong anti-inflammatory and insulin-sensitizing effects and modulation of microRNA expression towards a less inflammatory profile [139]. Inhibiting prostaglandins, TLR4, and NF-kB have all proven useful to counteract muscle wasting during cancer [33,140-142], so a compound that attenuates all of them at once should be even more powerful against CC.

The dissection of the possible mechanisms behind the protective effects of PUFAs against CC is the subject of several recent reviews [143-147], and the common thread is the acute phase response reduction, with lower serum levels of C-reactive protein (CRP), TNF $\alpha$, and IL-6, as the main effect underlying the CC prevention. In $\mathrm{C} 2 \mathrm{C} 12$ myoblasts, EPA abolished protein degradation induced by the proteolysis-inducing factor (PIF) by blocking AA release from membrane phospholipids, thus attenuating its conversion to prostaglandins E2 and F2 $\alpha$ and to 5-, 12-, and 15-hydroxyeicosatetraenoic acids [148]. In C2C12 myotubes, PUFAs not only inhibited protein degradation by acting on the PPAR $\gamma / \mathrm{NF}-\mathrm{kB}$ pathway, but also increased the rate of protein synthesis [149-151]. Moreover, both PUFAs and their lipid peroxidation products (4-hydroxyhexenal, HHE and HNE) have anti-cachexia effects by preventing the attenuation of myosin expression and myotube formation in $\mathrm{C} 2 \mathrm{C} 12$ cells exposed to medium conditioned with human lung tumor cells [152].

In MAC16-bearing mice, EPA antagonized CC-related muscle wasting through down-regulation of proteasome subunit expression and suppression of protein catabolism [153]. In their muscles, EPA also inhibited the rise in pro-inflammatory prostaglandin E2 in response to tumor-produced catabolic factors [154]. In Walker 256 tumor-bearing rats, supplementation of Oro Inca Oil, rich in $\alpha$-linolenic fatty acid (ALA), reduced the circulating levels of IL- 6 and TNF $\alpha$ and preserved body mass. However, it cannot be excluded that this effect was indirect because of the primary anticancer effect exerted by ALA, as indicated by reduced tumor growth [155]. Conversely, in C26-bearing mice, PUFAs improved neither muscles nor BWL but reversed the increase in size of livers and spleens [156], both signs of CC, as with anti-cachexia drugs at preclinical level $[157,158]$. On the other hand, a combination of nutritional supplements, which includes PUFAs, seems to reduce CC-related inflammation better and improve the functional performance in C26-bearing mice [159,160].

Similarly, even if some studies indicate that PUFAs may improve body weight, lean body mass, quality of life, and overall survival of patients with cancers, especially those with colorectal malignancies [147] by restraining inflammation [161], others report poor or no significant effect of PUFA diet supplementation on these same clinical parameters in patients with CC [162]. These discrepancies may be due to the large range of fish oil dosages and methods adopted (as discussed in [163]), as well as to the lack of knowledge about both the inflammatory and OS status of recruited patients, which might have helped identify those more responsive to PUFAs. Therefore, PUFA against CC is still under debate and the ongoing clinical trial "Enteral Omega 3 During Radiotherapy to Improve the Quality of Life and Functionality of Head and Neck Cancer Patients" (NCT03720158) might help clarify this issue.

However, PUFAs appear to have both antioxidant and prooxidant activities in a context-dependent manner. For instance, both EPA and DHA attenuate OS-induced damage through upregulation of the Nrf-2/HO-1 axis in vitro, in vascular endothelial cells and in adipocytes treated with $\mathrm{H}_{2} \mathrm{O}_{2}[164,165]$, and in vivo in models of brain ischemia [166] and cardiac ischemia/reperfusion injury [167]. Conversely, beneficial effects of PUFAs against malignancies seem to rely on PUFA-driven apoptosis in cancer cells by downregulating NF-KB [168] and increasing lipid peroxidation products to enhance cellular OS $[135,169]$. 
The PUFAs seem to counteract the hypermetabolism—hence the hypercatabolism—of skeletal muscles after severe burn trauma, which also exacerbates oxidative and mitochondrial stress [170]. Then too, in pancreatic cancer patients, dietary PUFA supplementation reduced the resting energy expenditure, whose elevation is indicative of hypermetabolism, ultimately increasing overall survival [171]. Similarly, since hyperlipidemia and the subsequent excessive fatty-acid-induced OS promote muscle atrophy during CC [172], the hypolipidemic effects of PUFAs, already highlighted at the end of the 1980s [173], may be beneficial and may also include a regulated expression of the uncoupling proteins (UCP). These are members of the mitochondrial carrier family involved in the control of ROS production, generated by the mitochondrial electron transport chain. Muscles of cachectic rodents show increased expression of both UCP-2 and UCP-3 [174-176], the latter also increasing in atrophying muscles of cancer patients [177]. Moreover, skeletal muscle UCP-3 expression is increased in pathologic conditions such as diabetes and starvation [178], with a concomitant increase in circulating free fatty acids (FFAs).

FFA levels are also high in cachectic patients [179], and it is known-at least in patients with hyperlipidemia - that PUFAs lower these levels [180]. Understanding whether hypolipidemic agents, like PUFAs, by means of the reduced circulating FFAs, can abolish UCP-3 expression in muscles, and thus the rate of OS, calls for further exploration.

\subsubsection{Natural Polyphenols}

Natural polyphenols comprise a group of heterogeneous organic molecules found in various plants and their derivatives, especially fruit and vegetables, but also herbs, cocoa, and tea. Polyphenols contain multiple phenol units and are classified based on the number and oxidation status of these primary units, as well as the presence of other functional groups. Numerous studies already support their potential health benefits, as modulators of OS, for managing and treating chronic diseases, including cardiovascular diseases and cancers [181-183]. Supporting evidence also exists for natural polyphenols to limit or restrain CC.

Epigallocatechin-3-gallate (EGCG), belonging to the flavonoid family (a class of plant-derived polyphenolic secondary metabolites), has anti-cachexia effects in vitro and in vivo. In differentiated murine myotubes subjected to serum starvation or exposed to TNF $\alpha, 10 \mu \mathrm{M}$ EGCG rescues protein synthesis and reduces the rate of protein degradation [184], protecting the cells from atrophy. In vivo, EGCG preserves skeletal muscle activity in dexamethasone-treated Wistar rats by increasing muscle acetylcholine sensitivity [185], while in LLC-bearing mice, it attenuated skeletal muscle atrophy by restraining NF-kB expression and downstream atrogenes [186]. Depending on the dose used, EGCG is a possible adjuvant in cancer therapy, because it can exert both antioxidant (low doses) and pro-oxidant (high doses) activities, thus preventing cancer onset or inducing cancer cell death, respectively [187]. For instance, daily intake of six tablets of green tea polyphenols (equivalent to $474 \mathrm{mg} /$ day of EGCG) attenuated ROS levels in plasma of patients with metastatic liver cancers undergoing hepatic arterial infusion chemotherapy [188].

Similarly to EGCG, curcumin, the main polyphenol component of curcuma extract, shows anti-inflammatory, antioxidant, antiatherosclerotic and neuroprotective activities [189]. In aged mice, it delays skeletal muscle degeneration by increasing the expression of some myokines with potential anti-atrophic activity to levels of young mice (adiponectin, Angptl4, S100a8, and Secreted protein acidic and cysteine rich (Sparc)) [190-192]. Interestingly, some of these myokines (S100a8 and Sparc) $[193,194]$ can be also increased by exercise in humans, indicating further similarities in the ways of molecular actions of nutraceuticals and physical activity (Figure 2). In vitro curcumin limited atrophy of PIF- or dexamethasone-treated C2C12 myotubes [195-197]; in vivo, it attenuated muscle wasting of MAC16-bearing mice [198]. Conversely, in rats bearing Yoshida AH-130 hepatomas, curcumin, despite its clear antitumoral effects, did not reverse CC [199]. In a retrospective study, patients with advanced pancreatic cancer treated for two months with curcumin lost more weight than controls, losing both fat and muscle [200]. The ongoing clinical trial CurChexia (NCT04208334) 
will evaluate the effect of curcumin $(4000 \mathrm{mg} /$ day $\times 60$ days $)$ against CC in patients with stage III-IV head-and-neck cancer, possibly clarifying the usefulness of curcumin against CC.

Mounting evidence shows that resveratrol, one of the main polyphenols in grapes, prevents muscle atrophy in a large number of catabolic conditions, such as disuse [201], aging [202,203], diabetes [204] and cancer cachexia [205]. It may also be useful to maintain a healthy weight against obesity, by modulating the secretion of many myokines, including irisin [206,207]. Resveratrol stimulates IGF1 signaling pathway, favoring hypertrophy in newly formed myotubes [208]. Some evidence suggests resveratrol may protect against ROS by restoring silent mating type information regulation 2 homolog-1 (SIRT1) levels, resulting in reduced mitochondrial-related apoptosis in myoblasts [209]. SIRT1 also seems to be the target by which resveratrol can blunt dexamethasone-driven catabolic effects in L6 myotubes [210]. Indeed, SIRT1 reduces muscle wasting by blocking the activation of FoxO1 and 3 and, thus, prevents catabolism by hindering the induction of atrogenes [211]. In C26-bearing mice, dietary supplementation with resveratrol inhibits both skeletal and cardiac muscle atrophy by impairing the DNA binding activity of the NF-kB (p65) subunit [212]. Most importantly, it has been recently shown that in a cachectic mouse models of pancreatic cancer, resveratrol is able to restrain muscle mass and strength by reducing the SIRT1-NOX4 signaling in muscle, being NOX4 a key modulator of ROS production [205]. However, intraperitoneal injection of resveratrol did not counteract muscle wasting in mice bearing LLC or Yoshida AH-130 hepatomas [213]. This illustrates how the route of administration and dose may affect bioavailability—and the bioactivity—of this and other nutraceuticals.

Quercetin, found in many fruits, vegetables, and seeds, is another SIRT1 inducer that has given promising results in pre-clinical settings. Quercetin has the potential to reduce OS-induced damage by acting on the TNF $\alpha$, AKT, PGC1 $\alpha$, and AMPK pathways (reviewed in [214]). In C2C12 cells, quercetin suppressed dexamethasone-induced expression of atrogin-1 and MuRF1, and myostatin too, in a concentration-dependent manner [215]. It also reduced dexamethasone-stimulated ROS production by reversing the mitochondrial membrane potential imbalance and apoptosis by regulating the Bax/Bcl-2 ratio [216]. In vivo, seven days pre-treatment with quercetin glycosides $(0.45 \% w / v$ in drinking water) prevented dexamethasone-induced gastrocnemius atrophy of mice, by downregulating atrogene expression [215]. In $\mathrm{Apc}^{\mathrm{Min} /+}$ mice, three weeks treatment with $25 \mathrm{mg} / \mathrm{kg}$ quercetin (oral gavage), after tumor development, reduced muscle atrophy by lowering plasma IL-6 and muscle STAT3 activation [217]. In the same animal model, daily quercetin given by gavage $(75 \mathrm{mg} / \mathrm{kg})$ also attenuated grip strength loss that was abolished by the overexpression of IL-6 via muscle electroporation [218], further indicating that the IL-6/STAT3 pathway is very likely the target of quercetin [217]. C26 tumor-bearing mice fed a quercetin-enriched diet ( $35 \mathrm{mg} / \mathrm{kg} / \mathrm{day}$ for 21 days) showed preserved body and hindlimb muscle weights [219], whilst daily intraperitoneal injections of quercetin (10 mg/kg for 15 days) prevented cachexia and increased survival of rats bearing Walker 256 tumor, though this effect may be related to an anticancer function of this flavonol [220].

Thus, a large body of evidence supports the use of polyphenols to halt muscle wasting in experimental models of CC. The different methods used for polyphenol supplementation call for more homogeneity in pre-clinical settings to understand their bioavailability and thus pave the way for large-cohort clinical studies to test the efficacy of these natural compounds against cachexia.

\subsubsection{Other Promising Nutraceuticals against Cancer Cachexia}

\section{Alkaloids}

Alkaloids are a group of naturally occurring chemical compounds that mostly contain basic nitrogen atoms and are used in clinical practice, particularly as anticancer agents [221]. Matrine is an alkaloid extracted from Sophora flavescens, a plant found widely in Asia with potent activities against various malignancies [222], including ovarian cancer [223], hepatocellular carcinoma [224], and human non-small-cell lung cancer [225]. Intraperitoneally injected matrine $(50 \mathrm{mg} / \mathrm{kg}$ for 5 or 11 days from 
the onset of cachexia) in C26-bearing mice lowered serum levels of TNF $\alpha$ and IL-6 and preserved body and gastrocnemius muscle weights [226], downregulating the expression of atrogenes in skeletal muscle [227]. Matrine also restrains C2C12 myotube atrophy and apoptosis induced by different atrophic stimuli (dexamethasone, TNF $\alpha$ and C26-conditioned medium) by activating the AKT/mTOR signaling pathway and inhibiting FoxO3-mediated atrogene expression [227]. Since matrine can influence mitochondrial function and ROS production in diverse cancer cells [228-230] and in oxidized LDL-stimulated macrophages [231], it remains to be established whether it can modulate OS also in muscles during CC.

Theophylline (1,3-dimethylxanthine) is a natural component of tea leaves and green coffee beans, with anti-inflammatory effects on cytokines, primarily produced by peripheral blood mononuclear cells [232]. In C2C12 myotubes, it reduces the proteolysis during hyperthermia-induced atrophy, and similarly to matrine, it partially reverses cachexia of rats bearing Yoshida AH-130 hepatoma, by lowering circulating TNF $\alpha$ levels [233]. Further investigation is needed to clarify the possible role of theophylline in other unrelated CC models such as nude mice bearing human renal cancer or LLC-bearing mice $[17,70]$.

Berberine is an isoquinoline alkaloid found in Berberis plants, with positive effects on various OS-mediated metabolic syndromes (reviewed in [234]) and in cancers. Berberine inhibits proliferation and induces apoptosis of colorectal cancer cells by impinging on JNK, p38 mitogen-activated protein kinase (MAPK), and NF-kB-based signaling, and modulating mitochondrial-ROS generation [235]. In nude mice bearing a human esophageal cancer cell line (YES-2) and in C26-bearing mice, oral supplementation with Coptidis rhizoma (containing the active component berberine) reduced tumor-derived IL-6 and BWL without changing food intake or tumor growth [236,237]. In mice inoculated with human colon cancer HCT116 cells, intraperitoneally injected berberine alleviated intestinal mucosal damage [238], a hallmark of CC that may further exacerbate systemic inflammation and cause food malabsorption, reducing food intake [239].

It is in this context that we recently investigated the anti-cachexia potential of trabectedin, a marine drug approved for the treatment of advanced solid tumors, and its less hepatotoxic analog lurbinectedin [240]. Both drugs greatly extended the lifespan of C26-bearing mice, and though lurbinectedin and trabectedin did not protect C26-bearing mice from muscle wasting, lurbinectedin strikingly reduced NF-kB/PAX7-related muscle inflammation and splenomegaly, without affecting tumor growth [157].

Other natural alkaloids have not been tested for managing cachexia but call for proper investigation. For instance, tomatidine is a natural small molecule found in the stems and leaves of tomato plants and unripe tomatoes. Tomatidine seems able to prevent oxidative damage under diabetic conditions in different tissues (retina, kidney, and skeletal muscles) [241]. It promotes skeletal muscle hypertrophy, by activation of the mTOR complex 1 (mTORC1) anabolic pathway, leading to increased strength and exercise capacity in young healthy mice. Most importantly, it reduces skeletal muscle atrophy during fasting and limb immobilization [242,243]. Therefore, it remains to be seen whether tomatidine, by antagonizing OS, will have a beneficial effect also against CC-mediated muscle atrophy.

\section{Triterpenoids}

Triterpenoids are a class of metabolites composed of three terpene units, biosynthesized in plants by the cyclization of squalene, a biochemical precursor of all steroids, widely used as chemo-preventive and anticancer agents [244], though their exact mechanisms of action have not been elucidated yet (reviewed in [245]).

Among the most important triterpenoids, ursolic acid, a pentacyclic triterpenoid found in various fruits and vegetables, displays anti-inflammatory, cardioprotective, and antitumoral properties. Ursolic acid exerts anticancer action by restraining various inflammation-related pathways, including STAT3, NF-kB, and MAPK (reviewed in [246]). As suggested by Shen and collaborators, it can also modulate ROS production, by triggering endoplasmic reticulum stress and autophagy via 
a ROS-dependent pathway, at least in human glioma cells [247]. In muscles, Ebert et al. found that ursolic acid promoted muscle growth through an mTORC1-dependent mechanism and reduced muscle atrophy and weakness in aged mice by repressing atrogene expression and transcription factor ATF4 activation [248]. In a mouse model of chronic kidney disease, with associated muscle wasting, 3 week treatment with ursolic acid $(100 \mathrm{mg} / \mathrm{kg} /$ day, by oral gavage) stimulated muscle protein synthesis, suppressed muscle protein degradation, and lowered plasma levels of inflammatory cytokines (TGF- $\beta$, IL-6, and TNF $\alpha$ ) [249]. Similarly, 5 day-treatment with ursolic acid (100 mg/kg/day, by oral gavage) in dexamethasone-treated rats protected them from muscle damage and weakness and reduced MuRF1 expression by limiting the nuclear translocation of FoxO1 [250].

Ginsenoside Rg1 belongs to the class of triterpene saponins and is the major pharmacologically active compound found in Panax ginseng [251]. It is one of the most famous traditional medicinal herbs, widely used for many centuries in Asian and Western countries. On account of its anti-inflammatory and antioxidant actions, it has been amply investigated for treating some chronic diseases [252-254]. Five week access to $0.4 \mathrm{mg} / \mathrm{mL}$ Rg1-containing water enhanced muscle size and function of healthy mice by increasing both the oxidative and glycolytic metabolism in muscle fibers. Ginsenoside Rg1 boosted mitochondrial oxidative metabolism and protein synthesis in muscles, the latter by activating S6K but inhibiting 4E-BP1 [255]. However, Lu et al. reported that C26-bearing mice orally treated with ginsenoside Rg1 (10.72 mg/kg in Phosphate-buffered saline (PBS) solution for 23 days from the onset of cachexia) had neither the protection of body weight nor gastrocnemius muscle mass but only reduced levels of TNF $\alpha$ and IL-6, further confirming that solely inhibition of proinflammatory pathways is not sufficient to block CC [256]. This study may contrast with data reported in [255], suggesting Rg1 as a valuable nutritional supplement for protecting muscles from atrophy. However, Rg1's lack of efficacy reported by $\mathrm{Lu}$ et al. might be explained by the lower cumulative dose used for treating the cachectic mice [256] compared to that given to healthy mice in the study by Jeong and coworkers [255].

Glycyrrhizin, a triterpene saponin extracted from licorice (Glycyrrhiza glabra), also claims numerous beneficial effects against chronic diseases (reviewed in [257]). For instance, it has anticancer properties, since it induces ROS-dependent apoptosis and cell cycle arrest, at least in HeLa cells [258]. It also has anti-cachexia effects in a mouse model of lung adenocarcinoma, though this may possibly be due to glycyrrhizin-mediated reduction in both tumor progression and cisplatin toxicity [259]. Furthermore, Ayeka et al. reported that C26-bearing mice orally given different licorice extracts for 14 days displayed decreased levels of TNF $\alpha$ and partial recovery in their body weight at the end of treatment [259]. Surprisingly, even if glycyrrhizin is known to inhibit HMGB1 [260], which seems increased in plasma and muscles of cachectic C26 mice [13] but not in muscles of LLC-bearing ones [261], it is still not clear whether the beneficial effects of this molecule against cachexia are related to the inhibition of HMGB1.

Further studies are needed to fully ascertain whether glycyrrhizin, as well as other triterpenoid compounds, are also useful for tackling CC in other unrelated preclinical models, and to confirm their role as a modulator of OS and/or inflammation during CC, before moving to clinical trials.

\section{Antioxidant and Anti-Inflammatory Effects of Exercise for Cancer Cachexia}

Physical activity has many beneficial effects and promotes overall wellbeing, improving muscle strength and metabolic function [262]. Metabolic adaptations to exercise are specific and depend on the nature of the exercise. Physical activity can be classified as "resistance/strength" or "endurance/aerobic" training. Resistance exercise consists of short periods of high contractile muscle performance against heavy external load, and when performed routinely, it mostly leads to increased muscle mass and strength and increased expression of glycolytic enzymes [263]. Instead, the endurance training consists of prolonged periods of low contractility, which results in acute rise in muscle ATP turnover and increased blood flow. It mainly promotes the shift of muscle fibers towards those relying more on oxidative metabolism, favoring intramuscular energy stores and mainly promoting more resistance to fatigue [264]. 
The American Cancer Society recommends cancer patients avoid inactivity and "take part in regular physical activity" of at least 150 min per week, including strength training exercises at least two days a week (https://www.cancer.org). Cancer Research UK supports these recommendations and suggests that all adults should try either $150 \mathrm{~min}$ of moderate-intensity activity or $75 \mathrm{~min}$ of vigorous activity per week (https://www.cancerresearchuk.org). They also state that "all adults should also try and build strength twice a week (e.g., weight training or yoga)" for preventing cancer and other pathologies. As regards these latter, both walking and vigorous exercise reduce the incidence of cardiovascular events among postmenopausal women [265] and strength training prevents sarcopenia (i.e., age-related muscle atrophy) [266].

Regular exercise seems to be a valid non-pharmacological approach to a wide variety of chronic diseases associated with low but chronic systemic inflammation, through amelioration of the inflammatory profile. Regular physical activity can reduce pro-inflammatory cytokines (i.e., TWEAK) [267] and raise the plasma levels of several anti-inflammatory ones, such as IL-10, IL-1 receptor antagonist (IL-1ra), and soluble TNF receptors-1 and -2 (sTNF-r1 and sTNF-r2), by monocytes [268-270]. IL-6 and other muscle-derived cytokines, referred to as myokines, are released by muscles in response to physical activity and mediate multiple beneficial metabolic effects on other organs (lipolysis and fat oxidation) [269,271-273].

Myostatin (also known as growth differentiation factor 8, GDF-8) is a myokine that negatively affects muscle mass and is reduced by both types of exercise [274,275], further linking inactivity with muscle loss. At the same time, myostatin has been found related to increased muscle wasting during cancer $[26,276]$, representing a possible target against CC. Follistatin by antagonizing myostatin has been shown to exert anti-atrophic effect at least in a specific subset of cancer-bearing mice, the inhibin-deficient ones [277]. Drawing on this evidence, physical exercise could potentially be a promising intervention strategy for the prevention and/or treatment of CC because of its simultaneous ability to boost muscle strength, lower overall fatigue, and reduce systemic inflammation [278]. A single bout of resistance exercise has been found able to decrease Fbxo40 in human muscles, suggesting increased protein synthesis [279], while if and how the expression of atrogin-1 and MuRF1 changes upon different types of exercise has given promiscuous results [279-282], perhaps depending on the different muscle analyzed.

Many pre-clinical studies in CC animal models have investigated the impact of both types of training on muscle physiology and the molecular signaling pathways involved (Figure 2). Alves and coworkers demonstrated that 16 days of high-intensity interval training, consisting of five intervals of $3 \mathrm{~min}$ treadmill running at $18 \mathrm{~m} / \mathrm{min}$ followed by 4 min running at $25 \mathrm{~m} / \mathrm{min}$, counteracted cachexia, prolonged survival, and also delayed tumor progression in LLC-bearing mice [283]. In a previous study, Gui et al. showed that four weeks of treadmill exercise $(12 \mathrm{~m} / \mathrm{min}$, for $60 \mathrm{~min} /$ day, five days/week) did not affect tumor growth [284] but partially rescued muscle weight and reduced atrogin-1 expression in gastrocnemius of LLC-bearing mice. Interestingly, Jee et al. demonstrated that four weeks of intense treadmill exercise ( $16 \mathrm{~m} / \mathrm{min}, 45 \mathrm{~min} /$ day, once every two days) was more efficient in limiting muscle atrophy and improving the quality of life and survival rate compared to moderate treadmill sessions ( $~ 8 \mathrm{~m} / \mathrm{min}, 45 \mathrm{~min} /$ day, once every 2 days) in a lung cancer mouse model of CC [285]. Similarly, eight weeks of moderate treadmill exercise $(18 \mathrm{~m} / \mathrm{min}, 1 \mathrm{~h}, 6$ days/week, $5 \%$ uphill) attenuated BWL in $\mathrm{Apc}^{\mathrm{Min} /+}$ mice electroporated with IL-6-containing plasmid in their quadriceps [286]. Treadmill exercise normalized insulin sensitivity and improved the muscle metabolism of $\mathrm{Apc} \mathrm{Min} /+^{+}$mice, by reducing the activation of AMPK and inducing AKT signaling, through improved muscle oxidative capacity [286]. Rats bearing the Yoshida AH-130 hepatomas and performing eight sessions of low-intensity treadmill exercise ( $15 \mathrm{~m} / \mathrm{min}, 30 \mathrm{~min} / \mathrm{session}$ ) had preserved muscle mass compared to sedentary counterparts, through suppression of the ubiquitin-proteasome pathway, increased hypoxia-inducible factor $1 \alpha$ (HIF-1 $\alpha$ ) levels, and phosphorylated AMPK [287].

Voluntary wheel running also preserved muscle mass and forelimb grip force in a transgenic mouse model of prostate adenocarcinoma, by reducing myostatin levels [288]. This type of exercise also 
extended the survival of C26-bearing mice and reduced their loss of muscle mass and function [289], by restraining atrogene expression and restoring the autophagic flux (i.e., lower LC3bII/LC3bI ratio and p62 levels) [290]. To mimic some of the effects of aerobic exercise, Pigna and coworkers treated C26-bearing mice with either AICAR, a pharmacological activator of AMPK [291], or rapamycin, an mTOR inhibitor [292]. Both drugs fully counteracted atrogene induction and muscle atrophy, by triggering the autophagic flux in Tibialis Anterior muscles of these mice. Similarly, trimetazidine (TMZ) given to C26-bearing mice exerted some exercise-like effects, such as boosting grip strength, fast-to-slow myofiber shift, PGC1 $\alpha$ induction with promotion of mitochondrial biogenesis, and protection of myofiber cross-sectional area (CSA) [293]. Coletti and collaborators further found that voluntary wheel running downregulated PAX7 expression and NF-kB activation in muscles from C26-bearing mice, preserving muscle mass and fiber size, thus removing the myogenic differentiation block observed in CC [294].

Furthermore, the role of combined resistance and endurance activity was explored in C26-bearing mice. Climbing a ladder inclined at $85^{\circ}$, with weights tied to their tails, was used for resistance training, while endurance exercise was carried out on the same day using a motorized wheel (5-9 $\mathrm{m} / \mathrm{min}$, $25 \mathrm{~min} /$ day) [295]. Mice were exercised for 4 days/week, for four weeks before tumor implantation and 11 days after $\mathrm{C} 26$ implantation. Both muscle mass and strength were improved by the combined training, resulting from modulation of both autophagy and proteasome-mediated degradation, as in [290]. Surprisingly, combined training did not rescue PGC1 $\alpha$ protein levels [295], which are typically induced by endurance training in this mouse model of CC [272,296], and amply reviewed in [67]. On the same line, Ballarò et al. showed that 12 days of a moderate mixed type of exercise on a hill motorized treadmill ( $11 \mathrm{~m} / \mathrm{min}, 45 \mathrm{~min}, 3$ days out of 4 ) in C26-bearing mice relieved muscle wasting, prevented loss of muscle strength, and partially reduced muscle OS, by improving the antioxidant capacity [84].

A beneficial effect of exercise on OS in muscle has been confirmed in Walker-256 tumor-bearing rats exposed for six weeks to resistance exercise, climbing a ladder apparatus with weights tied to their tails. This type of exercise mitigated BWL and muscle wasting in these rats by attenuating muscle OS and systemic inflammation [297]. However, Khamoui et al. found that three days per week for 11 weeks of ladder climbing with weights did not prevent C26-induced body and muscle weight loss in mice but induced the expression of genes associated with muscle damage and repair [298]. They found that only aerobic wheel running training partially rescued gastrocnemius mass, possibly by activating the mTOR pathway [298]. All these pre-clinical studies support the beneficial effect of physical exercise for counteracting CC, even if some discrepancies can be ascribed to the variety of cachexia models used, diverse background strains, and different exercise protocols.

Besides preclinical models, endurance as well as resistance training seems to offer therapeutic promise for CC patients too, perhaps, at least in part, because they promote antioxidant activity and anti-inflammatory response [84,299-301]. Both training programs, despite their different intensities, length, and frequency, improve muscle functional status, body composition, and promote the survival of patients with malignancies, suffering from cachexia [302,303]. In cancer survivors, on stopping radiation or chemotherapy, an endurance training program can mitigate cancer-related fatigue [304], compared to standard care, but also increases muscle strength, cardiorespiratory fitness, and reduces OS markers [305], once again highlighting the usefulness of chronic aerobic exercise in promoting antioxidant capacity.

Other studies also indicated the advantages of resistance exercise for CC patients. Progressive resistance training improves muscle strength and body weight in patients suffering from pancreatic cancer [306] or prostate cancer under radiation therapy [307] or breast cancers [308]. Resistance training also had beneficial effects in maintaining adequate quality of life in cachectic head-and-neck cancer patients undergoing radiotherapy $[309,310]$. Overall, it seems that resistance training is useful to improve muscle strength and composition in oncologic patients, while aerobic one to reduce the cardiovascularand metabolic-related complications of cancer and/or concomitant therapy [311]. 
Despite all this evidence and the recommendations of the American Cancer Society and Cancer Research UK, there is no consensus on the best modality of exercise training for cancer patients. From a general standpoint, since glycolytic fibers (primarily recruited by high-intensity strength training [312]) are more susceptible than oxidative myofibers to tumor-induced atrophy [14], it may seem logical to recommend that cancer patients at risk of developing CC do more endurance exercises to stimulate oxidative metabolic pathways and, thus, to target these specific fibers. Strenuous physical exercise is not feasible for patients who are more fragile because of aggressive therapies. Cancer patients should take moderate endurance/aerobic physical activity to potentiate muscle capacity and to detoxify ROS, through non-enzymatic and enzymatic antioxidant responses (discussed in [299]). An example of moderate physical activity includes three to five simple exercises, such as sit-to-stand, knee extension, or similar, repeated three times a day at home [313].

However, this kind of training has beneficial effects when endurance activity is constant and progressive, which is hard for CC patients who often suffer from chronic fatigue, anemia [314], and cardiovascular impairment, limiting their exercise capacity. Therefore, it is important to develop methods to enhance the effects of even low/moderate intensity exercise.

\section{Combination of Physical Activity and Nutraceuticals against Cancer Cachexia}

Various studies support the use of nutraceuticals (e.g., PUFAs, ursolic acid, cocoa flavanols, ginsenoside, and curcumin) not only for boosting physical performance-by rising the serum levels of some beneficial myokines too, such as irisin [315] — but also for preventing/reducing OS and, consequently, inflammation and muscle damage, elicited by intense physical training [316-321]. At least in the case of sarcopenia, the nutraceutical/exercise combination has already given promising results in aged subjects by improving their strength and physical performance and by reducing OS and muscle fatigue (reviewed in [322]). A few in vivo studies have investigated a multimodal approach as a feasible beneficial strategy for counteracting CC. For example, Penna and coworkers found that EPA supplementation of LLC-bearing mice subjected to treadmill $(14 \mathrm{~m} / \mathrm{min}, 45 \mathrm{~min}, 5$ days/week) partially rescued muscle strength and mass by raising PGC1 $\alpha$ levels and favoring muscle regeneration [323]. Of interest, resveratrol promoted muscle regeneration in C26-bearing mice exercised through 6 weeks of resistance training, climbing a ladder with weights tied to their tails [324].

Despite the scarce pre-clinical findings, some clinical trials have already evaluated this bimodal approach. A summary of them is included in Table 1. In 2017, a phase II trial with only 46 participants confirmed the feasibility and safety of a six-week multimodal intervention, which included PUFA supplementation, aerobic and resistance exercise, and anti-inflammatory therapy (celecoxib) for CC patients with advanced non-small-cell lung cancer (stage III-IV) or pancreatic cancer not eligible for curative therapy [325]. Based on the positive effects observed both on body weights and skeletal muscle mass but not on overall performance, phase III is ongoing under the name EudraCT 2013-002282-19 to definitely clarify the usefulness of this combined approach to CC.

To extend these findings, the ongoing multimodality exercise/nutrition anti-inflammatory treatment for cachexia (MENAC) phase III trial is currently enrolling 240 patients with diagnosis of lung or pancreatic cancer or cholangiocarcinoma. The intervention arm consists of six weeks of nutritional counseling, oral nutrition supplementation (including EPA), a mixed physical exercise program and ibuprofen, compared to standard care, for early prevention of cachexia [326]. Similarly, a recent single-arm intervention study assessed the feasibility of a multimodal intervention ( $2 \mathrm{~g}$ EPA/DHA via fish oil daily, regular dietary counseling, and unsupervised mixed physical exercise twice weekly) for CC management in 59 patients with non-small-cell lung cancer during the first three cycles of primary anti-neoplastic treatment. The gain in skeletal muscle mass was greater in patients receiving this multimodal intervention than in patients receiving standard care alone, though there were no differences in mean skeletal muscle, body weight, or physical function [327]. Adherence to the treatment plan and compliance with the intervention were among the contributing factors that favored the muscle gain in cancer patients [327]. 
Unfortunately, poor compliance in these trials, mostly due to deterioration of both psychological and health status [328], especially in completing physical exercise programs [325,327,329], may explain the scarce efficacy in ameliorating physical function and preventing body and muscle wasting in CC patients. The inclusion of advanced cachectic patients may further limit the feasibility of these promising therapies because of the high risk of dropouts. It would therefore be desirable to find other interventions, more easily to be completed.

A pilot study led by Schink and coworkers evaluated the effect of whole-body electromyostimulation (WB-EMS) to simultaneously stimulate muscles of the upper legs, arms, the bottom, the abdomen, the chest, and the back in advanced cancer patients under anticancer treatment. Twenty minutes of WB-EMS twice a week for 12 weeks combined with a very easy supervised exercise program and individualized nutritional support were more effective in sustaining skeletal muscle mass and improving physical function than standard dietary therapy alone [330]. An ongoing clinical trial (NCT03151291) is testing the combined approach of WB-EMS and specific nutritional support (including EPA) in patients with solid or hematological cancers. This study might pave the way to future large-scale trials for testing the feasibility and efficacy of this new exercise scheme, combined with appropriate nutraceuticals to improve not only body composition and muscle function but also oxidative/inflammatory status and, ultimately, the quality of life of CC patients. 
Table 1. Summary of human studies showing possible beneficial effects of nutraceutical or physical exercise, alone or combined, against cancer cachexia.

\begin{tabular}{|c|c|c|c|c|c|c|c|}
\hline $\begin{array}{l}\text { Nutraceutical/ } \\
\text { Exercise }\end{array}$ & Study Name & Study Type & $\begin{array}{l}\text { Number of } \\
\text { Participants }\end{array}$ & $\begin{array}{l}\text { Duration } \\
\text { (months) }\end{array}$ & Intervention & Summary of Findings & References \\
\hline n-3 PUFA & $\begin{array}{l}\text { Enteral omega } 3 \text { during } \\
\text { radiotherapy to improve the } \\
\text { quality of life and } \\
\text { functionality of head and } \\
\text { neck cancer patients }\end{array}$ & $\begin{array}{c}\text { Randomized } \\
\text { double-blinded, } \\
\text { controlled clinical trial }\end{array}$ & 86 & 39 & $\begin{array}{l}\text { Supplementation of an omega- } 3 \text { highly } \\
\text { concentrated substance }(5 \mathrm{~mL} / \mathrm{day} \text {, } \\
\text { containing } 2.25 \mathrm{~g} \text { of EPA and } 1.08 \mathrm{~g} \text { of } \\
\text { DHA) to the standard enteral diet } \\
\text { during radiotherapy }\end{array}$ & Ongoing & NCT03720158 \\
\hline \multirow{2}{*}{ Curcumin } & $\begin{array}{l}\text { The effects of curcumin } \\
\text { (diferuloylmethane) on body } \\
\text { composition of patients with } \\
\text { advanced pancreatic cancer }\end{array}$ & $\begin{array}{l}\text { Retrospective matched } \\
1: 2 \text { case-control study }\end{array}$ & 66 & 15 & $\begin{array}{l}\text { Supplementation of curcumin ( } 8000 \\
\mathrm{mg} / \text { day) for } 60 \text { days }\end{array}$ & $\begin{array}{l}\text { Reduced body weight, fat } \\
\text { and muscle tissues }\end{array}$ & [200] \\
\hline & $\begin{array}{l}\text { The effect of curcumin for } \\
\text { treatment of cancer } \\
\text { anorexia-cachexia syndrome } \\
\text { in patients with stage III-IV of } \\
\text { head and neck cancer } \\
\text { (CurChexia) }\end{array}$ & $\begin{array}{l}\text { Phase II, randomized } \\
\text { and double-blinded } \\
\text { clinical trial }\end{array}$ & 96 & 14 & $\begin{array}{l}\text { Supplementation of curcumin ( } 4000 \\
\mathrm{mg} / \text { day) for } 60 \text { days }\end{array}$ & Ongoing & NCT04208334 \\
\hline \multirow{3}{*}{$\begin{array}{l}\text { Resistance } \\
\text { training (RT) }\end{array}$} & $\begin{array}{l}\text { Physical exercise for patients } \\
\text { who suffer from weight loss } \\
\text { due to head and neck cancer } \\
\text { undergoing medical treatment }\end{array}$ & $\begin{array}{l}\text { Pilot study,2-arm, } \\
\text { randomized } \\
\text { controlled trial }\end{array}$ & 20 & 26 & $\begin{array}{l}\text { Progressive RT (PRT) }(30 \mathrm{~min}, 3 \\
\text { times/week) for } 6 \text { weeks, during } \\
\text { the radiotherapy }\end{array}$ & $\begin{array}{l}\text { The training program is } \\
\text { safe and feasible } \\
\text { Improved general fatigue } \\
\text { and quality of life }\end{array}$ & [309] \\
\hline & $\begin{array}{l}\text { PRT rebuilds lean body mass } \\
\text { in head and neck cancer } \\
\text { patients after radiotherapy: } \\
\text { DAHANCA 25B trial }\end{array}$ & $\begin{array}{c}\text { Multi-center, } \\
\text { randomized, } \\
\text { stratified and } \\
\text { parallel-grouped study }\end{array}$ & 41 & 19 & $\begin{array}{l}\text { Two group of patients with completed } \\
\text { anti-neoplastic therapy: } \\
\text { - Early Exercise: initiated } 12 \text { weeks } \\
\text { of PRT followed by } 12 \text { weeks of } \\
\text { self-chosen physical activity } \\
\text { - Delayed Exercise: initiated } 12 \\
\text { weeks of self-chosen physical } \\
\text { activity followed by } 12 \text { weeks } \\
\text { of PRT }\end{array}$ & $\begin{array}{l}\text { Increased lean body mass } \\
\text { and muscle strength in } \\
\text { both groups }\end{array}$ & [310] \\
\hline & $\begin{array}{l}\text { Exercise intervention study } \\
\text { for pancreatic cancer patients } \\
\text { (SUPPORT) }\end{array}$ & $\begin{array}{l}\text { Randomized } \\
\text { controlled } \\
\text { intervention trial }\end{array}$ & 65 & 38 & $\begin{array}{l}\text { Supervised RT or home-based RT ( } 2 \\
\text { times/week) for } 6 \text { months during and } \\
\text { after chemotherapy }\end{array}$ & $\begin{array}{l}\text { Improved muscle strength } \\
\text { supervised RT is more } \\
\text { effective than } \\
\text { home-based RT }\end{array}$ & [306] \\
\hline $\begin{array}{l}\text { Resistance and } \\
\text { aerobic training }\end{array}$ & $\begin{array}{l}\text { Oxidative stress and fitness } \\
\text { changes in cancer patients } \\
\text { after exercise training }\end{array}$ & $\begin{array}{l}\text { Pilot study, } \\
\text { pseudo-randomized trial }\end{array}$ & 22 & 3 & $\begin{array}{l}\text { Supervised resistance and aerobic } \\
\text { training ( } 60 \mathrm{~min} / \text { day) for } 10 \text { weeks, after } \\
6 \text { weeks of completing } \\
\text { anti-neoplastic treatment }\end{array}$ & $\begin{array}{l}\text { Increased muscular } \\
\text { strength, } \\
\text { antioxidant capacity } \\
\text { Decreased markers of } \\
\text { protein and } \\
\text { DNA oxidation }\end{array}$ & [305] \\
\hline
\end{tabular}


Table 1. Cont.

\begin{tabular}{|c|c|c|c|c|c|c|c|}
\hline $\begin{array}{l}\text { Nutraceutical/ } \\
\text { Exercise }\end{array}$ & Study Name & Study Type & $\begin{array}{l}\text { Number of } \\
\text { Participants }\end{array}$ & $\begin{array}{l}\text { Duration } \\
\text { (months) }\end{array}$ & Intervention & Summary of Findings & References \\
\hline \multirow{4}{*}{$\begin{array}{l}\text { Multimodal } \\
\text { intervention }\end{array}$} & $\begin{array}{l}\text { A feasibility study of } \\
\text { multimodal } \\
\text { exercise/nutrition/ } \\
\text { anti-inflammatory treatment } \\
\text { for cachexia } \\
\text { (the Pre-MENAC) }\end{array}$ & $\begin{array}{l}\text { Phase II, randomized } \\
\text { and open-label } \\
\text { feasibility trial }\end{array}$ & 46 & 38 & $\begin{array}{l}\text { Celecoxib ( } 300 \mathrm{mg} / \text { day })+ \text { EPA ( } 2 \text { g/day) } \\
+ \text { home-based aerobic ( } 30 \mathrm{~min} \text {, } \\
2 \text { times/week) and RT ( } 20 \mathrm{~min}, \\
3 \text { times/week) for } 6 \text { weeks during the } \\
\text { chemotherapy }\end{array}$ & $\begin{array}{l}\text { A multimodal } \\
\text { intervention is feasible } \\
\text { and safe } \\
\text { No significant effect on } \\
\text { physical performance or } \\
\text { muscle mass }\end{array}$ & [325] \\
\hline & $\begin{array}{l}\text { Multimodal intervention for } \\
\text { cachexia in advanced cancer } \\
\text { patients undergoing } \\
\text { chemotherapy (MENAC) }\end{array}$ & $\begin{array}{l}\text { Phase III, randomized } \\
\text { controlled trial }\end{array}$ & 240 & 69 & $\begin{array}{l}\text { Ibuprofen }(1200 \mathrm{mg} / \text { day })+\text { EPA }(2 \mathrm{~g} / \text { day }) \\
+ \text { + DHA ( } 1 \mathrm{~g} / \text { day })+\mathrm{RT}(3 \text { times/week }) \text { and } \\
\text { aerobic training }(2 \text { times/week) for } 6 \\
\text { weeks during the chemotherapy }\end{array}$ & Ongoing & [326] \\
\hline & $\begin{array}{l}\text { Feasibility of a multimodal } \\
\text { intervention on malnutrition } \\
\text { in patients with lung cancer } \\
\text { during primary } \\
\text { anti-neoplastic treatment }\end{array}$ & $\begin{array}{l}\text { Single arm } \\
\text { non-randomized trial }\end{array}$ & 58 & 15 & $\begin{array}{l}\text { EPA/DHA ( } 2 \text { g/day) via fish oil daily }+ \\
\text { resistance and aerobic training } \\
\text { ( } 2 \text { times/week) during the first three } \\
\text { cycles of anti-neoplastic treatment }\end{array}$ & $\begin{array}{l}\text { Gain in skeletal } \\
\text { muscle mass. } \\
\text { No effect on mean skeletal } \\
\text { muscle, body weight or } \\
\text { physical function }\end{array}$ & [327] \\
\hline & $\begin{array}{l}\text { Feasibility of early } \\
\text { multimodal interventions for } \\
\text { elderly patients with } \\
\text { advanced pancreatic and } \\
\text { non-small-cell lung cancer } \\
\text { (NEXTAC study) }\end{array}$ & $\begin{array}{l}\text { Multicenter } \\
\text { prospective } \\
\text { randomized single } \\
\text { arm, phase II study }\end{array}$ & 30 & 24 & $\begin{array}{l}\text { Branched-chain aminoacids ( } 2.5 \mathrm{~g} / \text { day), } \\
\text { coenzyme Q10 ( } 30 \mathrm{mg} / \text { day), and } \\
\text { L-carnitine }(50 \mathrm{mg} / \text { day) + supervised } \\
\text { home-based low intensity RT } \\
\text { ( } 20-30 \mathrm{~min} / \text { day) for } 8 \text { weeks during the } \\
\text { chemotherapy }\end{array}$ & $\begin{array}{l}\text { Multimodal intervention } \\
\text { shows excellent } \\
\text { compliance and safety }\end{array}$ & [313] \\
\hline \multirow{2}{*}{$\begin{array}{c}\begin{array}{c}\text { Whole-body } \\
\text { electro- }\end{array} \\
\text { myostimulation } \\
\text { (WB-EMS) + } \\
\text { individualized } \\
\text { nutritional } \\
\text { support } \pm \\
\text { nutraceuticals }\end{array}$} & $\begin{array}{l}\text { Effects of WB-EMS combined } \\
\text { with individualized } \\
\text { nutritional support on body } \\
\text { composition in patients with } \\
\text { advanced cancer: a controlled } \\
\text { pilot trial }\end{array}$ & $\begin{array}{l}\text { Non-randomized } \\
\text { controlled pilot trial }\end{array}$ & 131 & 60 & $\begin{array}{l}\text { WB-EMS training ( } 2 \text { times/week, } 20 \mathrm{~min} \text { ) } \\
+ \text { individualized nutritional support } \\
\text { (dietary advices: daily protein intake } \\
>1 \mathrm{~g} / \mathrm{kg} \text { bodyweight) for } 12 \text { weeks } \\
\text { during anti-neoplastic treatment }\end{array}$ & $\begin{array}{l}\text { Supervised WB-EMS } \\
\text { training is safe } \\
\text { WB-EMS, combined with } \\
\text { nutritional support, } \\
\text { shows promising effects } \\
\text { against muscle wasting } \\
\text { and on physical function }\end{array}$ & [330] \\
\hline & $\begin{array}{l}\text { Effects of WB-EMS and } \\
\text { Specific Dietary Supplements } \\
\text { on Cancer Patients }\end{array}$ & $\begin{array}{l}\text { Randomized with } \\
\text { parallel assignment }\end{array}$ & 200 & 29 & $\begin{array}{l}\text { WB-EMS training ( } 2 \text { times/week, } 20 \mathrm{~min}) \\
+ \text { individualized nutritional support } \pm \\
\text { supplementation of } \mathrm{HMB}(3 \mathrm{~g} / \mathrm{day}) \text { or LC } \\
(4 \mathrm{~g} / \text { day) or EPA ( } 2.2 \mathrm{~g} / \text { day) for } 12 \text { weeks } \\
\text { during curative or palliative } \\
\text { anti-neoplastic treatment }\end{array}$ & Ongoing & NCT03151291 \\
\hline
\end{tabular}

Abbreviations: EPA: eicosapentaenoic acid; DHA: docosahexaenoic acid; PUFA: polyunsaturated fatty acid; RT: resistance training; PRT: progressive resistance training: WB-EMS: whole-body electromyostimulation; HMB: $\beta$-hydroxy- $\beta$-methylbutyrate; LC: L-carnitine. 


\title{
6. Conclusions and Prospects
}

In summary, current evidence suggests that nutraceuticals have the potential to limit CC, although optimal therapy may depend on several factors, especially bioavailability. For instance, new nutraceutical formulations are needed for curcumin supplementation [331], possibly using nanoparticles or liposomes, to increase the bioavailability and subsequently the clinical efficacy of the nutraceutical [331].

Strategies aimed at fortifying the gut barrier function in CC patients-a factor that limits their capacity to absorb both vital nutrients and also nutraceuticals [332]—should be pursued. On the other hand, some standard therapeutic strategies are based on ROS-generating drugs to induce cancer cell apoptosis, so antioxidant nutraceuticals in supra-physiological doses may be detrimental, since they may favor tumor growth and subsequently CC progression. Similarly, combinations of antioxidants may be trivial and counterproductive as already shown in pre-clinical CC models [85]. Therefore, further investigation of patients' redox status, before starting and during treatment may be useful not only for staging CC patients but also for planning early and appropriate target medication, which may include nutraceuticals. For instance, measuring biomarkers of $\mathrm{OS}$ (such as $\mathrm{F}_{2}$-isoprostanes and 8-hydroxydeoxyguanosine) in body fluids (e.g., urine) may be rapid and feasible for constant monitoring of OS status in these patients [333].

Regarding physical exercise, endurance/aerobic training may be more beneficial than resistance training in counteracting muscle atrophy and improving the redox status during CC. However, the poor compliance of CC patients performing regular exercise is a major limitation. Thus, nutraceuticals may be a valid support against CC, especially in advanced stages, to potentiate the beneficial effect of a more moderate and attainable exercise program. Nevertheless, in this context too, finely tuned redox status regulation during exercise is crucial for muscle homeostasis, and an excess of antioxidant nutraceuticals may be detrimental due to alterations of the signaling pathways involved in muscle adaptation to physical exercise (reviewed in [334]).

WB-EMS may be useful to increase CC patients' adherence to an exercise plan, but more effort, especially in pre-clinical practice, is needed for a better understanding of whether and how physical exercise and nutraceuticals can act in synergy and/or antagonism to promote the molecular mechanisms against CC-related atrophy. Filling the existing scientific gaps may be helpful to design larger and more homogeneous clinical trials to test the efficacy of this bimodal approach in CC.

Funding: This research was funded by the ASSOCIAZIONE ITALIANA RICERCA SUL CANCRO (AIRC IG grant number 19927 to R.P.) and by the National Institute of Arthritis and Musculoskeletal and Skin Diseases (grant number R01AR070200 to J.J.B).

Acknowledgments: We are highly grateful to Sara Grazia Maria Piccirillo for the time dedicated for critical reading of the manuscript and to Stefania Ferramosca and Ettore Zuccato for general advice. The Mario Negri Institute's in-house editor has revised the text.

Conflicts of Interest: The authors declare no conflict of interest. The funders had no role in the design of the study; in the collection, analyses, or interpretation of data; in the writing of the manuscript, or in the decision to publish the results.

\author{
Abbreviations \\ 4E-BP1 eukaryotic translation initiation factor 4E-binding protein 1 \\ AA arachidonic acid \\ ALA $\quad \alpha$-linolenic fatty acid \\ ALS amyotrophic lateral sclerosis \\ AMPK AMP-activated protein kinase \\ $\mathrm{Apc}^{\mathrm{Min} /+} \quad$ adenomatous polyposis coli, multiple intestinal neoplasia \\ ASCO American Society of Clinical Oncology \\ ATF4 activating transcription factor 4 \\ BMI body mass index \\ BWL body weight loss
}




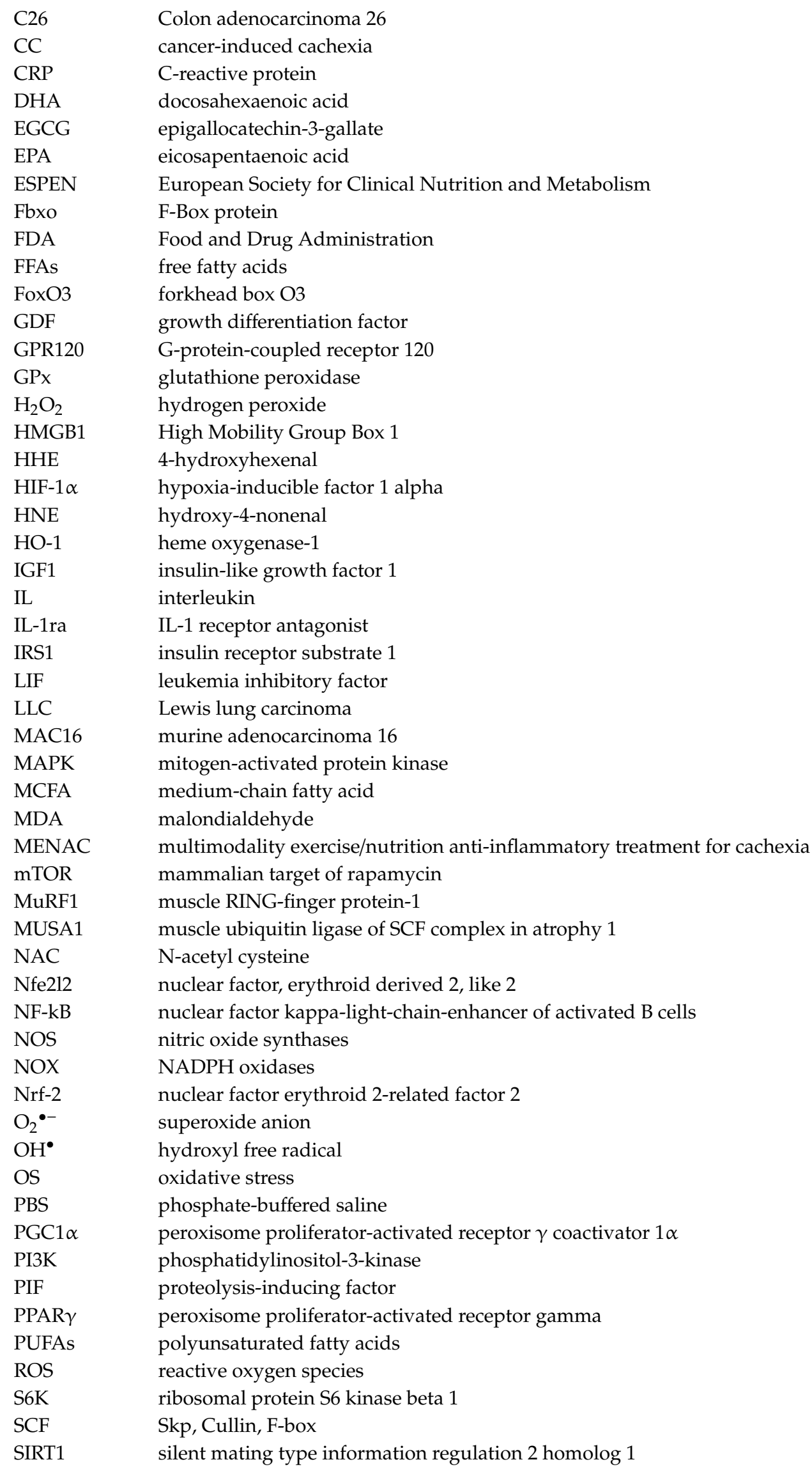




$\begin{array}{ll}\text { SOD } & \text { superoxide dismutase } \\ \text { Sparc } & \text { Secreted protein acidic and cysteine rich } \\ \text { STAT3 } & \text { signal transducer and activator of transcription 3 } \\ \text { sTNF-r } & \text { soluble TNF receptor } \\ \text { Tak1 } & \text { transforming growth factor- } \beta \text { activated kinase } \\ \text { TGF } \beta & \text { transforming growth factor beta } \\ \text { TLR4 } & \text { Toll-like receptor } 4 \\ \text { TMZ } & \text { trimetazidine } \\ \text { TNF } \alpha & \text { tumor necrosis factor alpha } \\ \text { TORC1 } & \text { mTOR complex } \\ \text { TRAF6 } & \text { TNF receptor-associated factor } 6 \\ \text { TWEAK } & \text { TNF-related weak inducer of apoptosis } \\ \text { UCP } & \text { uncoupling proteins } \\ \text { UPS } & \text { ubiquitin proteasome system } \\ \text { WB-EMS } & \text { whole-body electromyostimulation }\end{array}$

\section{References}

1. Tisdale, M.J. Mechanisms of cancer cachexia. Physiol. Rev. 2009, 89, 381-410. [CrossRef]

2. Fearon, K.; Strasser, F.; Anker, S.D.; Bosaeus, I.; Bruera, E.; Fainsinger, R.L.; Jatoi, A.; Loprinzi, C.; MacDonald, N.; Mantovani, G.; et al. Definition and classification of cancer cachexia: An international consensus. Lancet Oncol. 2011, 12, 489-495. [CrossRef]

3. Miyamoto, Y.; Hanna, D.L.; Zhang, W.; Baba, H.; Lenz, H.-J. Molecular Pathways: Cachexia Signaling-A Targeted Approach to Cancer Treatment. Clin. Cancer Res. 2016, 22, 3999-4004. [CrossRef] [PubMed]

4. Houten, L.; Reilley, A.A. An investigation of the cause of death from cancer. J. Surg. Oncol. 1980, 13, 111-116. [CrossRef] [PubMed]

5. Roberts, B.M.; Ahn, B.; Smuder, A.J.; Al-Rajhi, M.; Gill, L.C.; Beharry, A.W.; Powers, S.K.; Fuller, D.D.; Ferreira, L.F.; Judge, A.R. Diaphragm and ventilatory dysfunction during cancer cachexia. FASEB J. 2013, 27, 2600-2610. [CrossRef] [PubMed]

6. Blauwhoff-Buskermolen, S.; Langius, J.A.E.; Becker, A.; Verheul, H.M.W.; de van der Schueren, M.A.E. The influence of different muscle mass measurements on the diagnosis of cancer cachexia. J. Cachexia Sarcopenia Muscle 2017, 8, 615-622. [CrossRef] [PubMed]

7. Evans, W.J.; Morley, J.E.; Argilés, J.; Bales, C.; Baracos, V.; Guttridge, D.; Jatoi, A.; Kalantar-Zadeh, K.; Lochs, H.; Mantovani, G.; et al. Cachexia: A new definition. Clin. Nutr. 2008, 27, 793-799. [CrossRef]

8. Arends, J.; Baracos, V.; Bertz, H.; Bozzetti, F.; Calder, P.C.; Deutz, N.E.P.; Erickson, N.; Laviano, A.; Lisanti, M.P.; Lobo, D.N.; et al. ESPEN expert group recommendations for action against cancer-related malnutrition. Clin. Nutr. 2017, 36, 1187-1196. [CrossRef]

9. Garcia, D.O.; Thomson, C.A. Physical activity and cancer survivorship. Nutr. Clin. Pract. 2014, $29,768-779$. [CrossRef]

10. Gupta, S.C.; Kim, J.H.; Prasad, S.; Aggarwal, B.B. Regulation of survival, proliferation, invasion, angiogenesis, and metastasis of tumor cells through modulation of inflammatory pathways by nutraceuticals. Cancer Metastasis Rev. 2010, 29, 405-434. [CrossRef]

11. Roeland, E.J.; Bohlke, K.; Baracos, V.E.; Bruera, E.; del Fabbro, E.; Dixon, S.; Fallon, M.; Herrstedt, J.; Lau, H.; Platek, M.; et al. Management of Cancer Cachexia: ASCO Guideline. J. Clin. Oncol. 2020, 38, 2438-2453. [CrossRef] [PubMed]

12. Argilés, J.M.; Busquets, S.; Stemmler, B.; López-Soriano, F.J. Cancer cachexia: Understanding the molecular basis. Nat. Rev. Cancer 2014, 14, 754-762. [CrossRef] [PubMed]

13. Luo, Y.; Yoneda, J.; Ohmori, H.; Sasaki, T.; Shimbo, K.; Eto, S.; Kato, Y.; Miyano, H.; Kobayashi, T.; Sasahira, T.; et al. Cancer usurps skeletal muscle as an energy repository. Cancer Res. 2014, 74, 330-340. [CrossRef]

14. Ciciliot, S.; Rossi, A.C.; Dyar, K.A.; Blaauw, B.; Schiaffino, S. Muscle type and fiber type specificity in muscle wasting. Int. J. Biochem. Cell Biol. 2013, 45, 2191-2199. [CrossRef]

15. Melville, S.; McNurlan, M.A.; Calder, A.G.; Garlick, P.J. Increased protein turnover despite normal energy metabolism and responses to feeding in patients with lung cancer. Cancer Res. 1990, 50, 1125-1131. [PubMed] 
16. Argilés, J.M.; Busquets, S.; Toledo, M.; López-Soriano, F.J. The role of cytokines in cancer cachexia. Curr. Opin. Support. Palliat. Care 2009, 3, 263-268. [CrossRef]

17. Pretto, F.; Ghilardi, C.; Moschetta, M.; Bassi, A.; Rovida, A.; Scarlato, V.; Talamini, L.; Fiordaliso, F.; Bisighini, C.; Damia, G.; et al. Sunitinib prevents cachexia and prolongs survival of mice bearing renal cancer by restraining STAT3 and MuRF-1 activation in muscle. Oncotarget 2015, 6, 3043-3054. [CrossRef]

18. Zhou, X.; Wang, J.L.; Lu, J.; Song, Y.; Kwak, K.S.; Jiao, Q.; Rosenfeld, R.; Chen, Q.; Boone, T.; Simonet, W.S.; et al. Reversal of cancer cachexia and muscle wasting by ActRIIB antagonism leads to prolonged survival. Cell 2010, 142, 531-543. [CrossRef]

19. Alvarez, B.; Quinn, L.S.; Busquets, S.; Quiles, M.T.; Lopez-Soriano, F.J.; Argiles, J.M. Tumor necrosis factor-alpha exerts interleukin-6-dependent and -independent effects on cultured skeletal muscle cells. Biochim. Biophys. Acta 2002, 1542, 66-72. [CrossRef]

20. Zhang, L.; Du, J.; Hu, Z.; Han, G.; Delafontaine, P.; Garcia, G.; Mitch, W.E. IL-6 and serum amyloid A synergy mediates angiotensin II-induced muscle wasting. J. Am. Soc. Nephrol. 2009, 20, 604-612. [CrossRef]

21. Wiedenmann, B.; Malfertheiner, P.; Friess, H.; Ritch, P.; Arseneau, J.; Mantovani, G.; Caprioni, F.; Van Cutsem, E.; Richel, D.; DeWitte, M.; et al. A multicenter, phase II study of infliximab plus gemcitabine in pancreatic cancer cachexia. J. Support. Oncol 2008, 6, 18-25. [PubMed]

22. Prado, B.L.; Qian, Y. Anti-cytokines in the treatment of cancer cachexia. Ann. Palliat. Med. 2019, 8, 67-79. [CrossRef] [PubMed]

23. Kandarian, S.C.; Nosacka, R.L.; Delitto, A.E.; Judge, A.R.; Judge, S.M.; Ganey, J.D.; Moreira, J.D.; Jackman, R.W. Tumour-derived leukaemia inhibitory factor is a major driver of cancer cachexia and morbidity in C26 tumour-bearing mice. J. Cachexia Sarcopenia Muscle 2018, 9, 1109-1120. [CrossRef] [PubMed]

24. Johnston, A.J.; Murphy, K.T.; Jenkinson, L.; Laine, D.; Emmrich, K.; Faou, P.; Weston, R.; Jayatilleke, K.M.; Schloegel, J.; Talbo, G.; et al. Targeting of Fn14 Prevents Cancer-Induced Cachexia and Prolongs Survival. Cell 2015, 162, 1365-1378. [CrossRef] [PubMed]

25. Loumaye, A.; de Barsy, M.; Nachit, M.; Lause, P.; Frateur, L.; van Maanen, A.; Trefois, P.; Gruson, D.; Thissen, J.-P. Role of Activin A and myostatin in human cancer cachexia. J. Clin. Endocrinol. Metab. 2015, 100, 2030-2038. [CrossRef]

26. Gallot, Y.S.; Durieux, A.-C.; Castells, J.; Desgeorges, M.M.; Vernus, B.; Plantureux, L.; Rémond, D.; Jahnke, V.E.; Lefai, E.; Dardevet, D.; et al. Myostatin gene inactivation prevents skeletal muscle wasting in cancer. Cancer Res. 2014, 74, 7344-7356. [CrossRef]

27. Kir, S.; Komaba, H.; Garcia, A.P.; Economopoulos, K.P.; Liu, W.; Lanske, B.; Hodin, R.A.; Spiegelman, B.M. PTH/PTHrP Receptor Mediates Cachexia in Models of Kidney Failure and Cancer. Cell Metab. 2016, 23, 315-323. [CrossRef]

28. Suriben, R.; Chen, M.; Higbee, J.; Oeffinger, J.; Ventura, R.; Li, B.; Mondal, K.; Gao, Z.; Ayupova, D.; Taskar, P.; et al. Antibody-mediated inhibition of GDF15-GFRAL activity reverses cancer cachexia in mice. Nat. Med. 2020, 26, 1264-1270. [CrossRef]

29. Okugawa, Y.; Toiyama, Y.; Hur, K.; Yamamoto, A.; Yin, C.; Ide, S.; Kitajima, T.; Fujikawa, H.; Yasuda, H.; Koike, Y.; et al. Circulating miR-203 derived from metastatic tissues promotes myopenia in colorectal cancer patients. J. Cachexia Sarcopenia Muscle 2019, 10, 536-548. [CrossRef]

30. Wu, Q.; Sun, S.; Li, Z.; Yang, Q.; Li, B.; Zhu, S.; Wang, L.; Wu, J.; Yuan, J.; Wang, C.; et al. Breast cancer-released exosomes trigger cancer-associated cachexia to promote tumor progression. Adipocyte 2019, 8, 31-45. [CrossRef]

31. He, W.A.; Calore, F.; Londhe, P.; Canella, A.; Guttridge, D.C.; Croce, C.M. Microvesicles containing miRNAs promote muscle cell death in cancer cachexia via TLR7. Proc. Natl. Acad. Sci. USA 2014, 111, 4525-4529. [CrossRef] [PubMed]

32. Lecker, S.H.; Jagoe, R.T.; Gilbert, A.; Gomes, M.; Baracos, V.; Bailey, J.; Price, S.R.; Mitch, W.E.; Goldberg, A.L. Multiple types of skeletal muscle atrophy involve a common program of changes in gene expression. FASEB J. 2004, 18, 39-51. [CrossRef] [PubMed]

33. Cai, D.; Frantz, J.D.; Tawa, N.E.; Melendez, P.A.; Oh, B.-C.; Lidov, H.G.W.; Hasselgren, P.-O.; Frontera, W.R.; Lee, J.; Glass, D.J.; et al. IKKbeta/NF-kappaB activation causes severe muscle wasting in mice. Cell 2004, 119, 285-298. [CrossRef] [PubMed] 
34. Sandri, M.; Sandri, C.; Gilbert, A.; Skurk, C.; Calabria, E.; Picard, A.; Walsh, K.; Schiaffino, S.; Lecker, S.H.; Goldberg, A.L. Foxo transcription factors induce the atrophy-related ubiquitin ligase atrogin-1 and cause skeletal muscle atrophy. Cell 2004, 117, 399-412. [CrossRef]

35. Segatto, M.; Fittipaldi, R.; Pin, F.; Sartori, R.; Dae Ko, K.; Zare, H.; Fenizia, C.; Zanchettin, G.; Pierobon, E.S.; Hatakeyama, S.; et al. Epigenetic targeting of bromodomain protein BRD4 counteracts cancer cachexia and prolongs survival. Nat. Commun. 2017, 8, 1707. [CrossRef]

36. Bonetto, A.; Aydogdu, T.; Kunzevitzky, N.; Guttridge, D.C.; Khuri, S.; Koniaris, L.G.; Zimmers, T.A. STAT3 activation in skeletal muscle links muscle wasting and the acute phase response in cancer cachexia. PLOS ONE 2011, 6, e22538. [CrossRef]

37. Clarke, B.A.; Drujan, D.; Willis, M.S.; Murphy, L.O.; Corpina, R.A.; Burova, E.; Rakhilin, S.V.; Stitt, T.N.; Patterson, C.; Latres, E.; et al. The E3 Ligase MuRF1 degrades myosin heavy chain protein in dexamethasone-treated skeletal muscle. Cell Metab. 2007, 6, 376-385. [CrossRef]

38. Cohen, S.; Brault, J.J.; Gygi, S.P.; Glass, D.J.; Valenzuela, D.M.; Gartner, C.; Latres, E.; Goldberg, A.L. During muscle atrophy, thick, but not thin, filament components are degraded by MuRF1-dependent ubiquitylation. J. Cell Biol. 2009, 185, 1083-1095. [CrossRef]

39. Lagirand-Cantaloube, J.; Cornille, K.; Csibi, A.; Batonnet-Pichon, S.; Leibovitch, M.P.; Leibovitch, S.A. Inhibition of atrogin-1/MAFbx mediated MyoD proteolysis prevents skeletal muscle atrophy in vivo. PLoS ONE 2009, 4, e4973. [CrossRef]

40. Yuan, L.; Han, J.; Meng, Q.; Xi, Q.; Zhuang, Q.; Jiang, Y.; Han, Y.; Zhang, B.; Fang, J.; Wu, G. Muscle-specific E3 ubiquitin ligases are involved in muscle atrophy of cancer cachexia: An in vitro and in vivo study. Oncol. Rep. 2015, 33, 2261-2268. [CrossRef]

41. Kumar, A.; Bhatnagar, S.; Paul, P.K. TWEAK and TRAF6 regulate skeletal muscle atrophy. Curr. Opin. Clin. Nutr. Metab. Care 2012, 15, 233-239. [CrossRef] [PubMed]

42. Paul, P.K.; Kumar, A. TRAF6 coordinates the activation of autophagy and ubiquitin-proteasome systems in atrophying skeletal muscle. Autophagy 2011, 7, 555-556. [CrossRef] [PubMed]

43. Paul, P.K.; Gupta, S.K.; Bhatnagar, S.; Panguluri, S.K.; Darnay, B.G.; Choi, Y.; Kumar, A. Targeted ablation of TRAF6 inhibits skeletal muscle wasting in mice. J. Cell Biol. 2010, 191, 1395-1411. [CrossRef] [PubMed]

44. Kwak, K.S.; Zhou, X.; Solomon, V.; Baracos, V.E.; Davis, J.; Bannon, A.W.; Boyle, W.J.; Lacey, D.L.; Han, H.Q. Regulation of protein catabolism by muscle-specific and cytokine-inducible ubiquitin ligase E3alpha-II during cancer cachexia. Cancer Res. 2004, 64, 8193-8198. [CrossRef] [PubMed]

45. Aniort, J.; Stella, A.; Philipponnet, C.; Poyet, A.; Polge, C.; Claustre, A.; Combaret, L.; Béchet, D.; Attaix, D.; Boisgard, S.; et al. Muscle wasting in patients with end-stage renal disease or early-stage lung cancer: Common mechanisms at work. J. Cachexia Sarcopenia Muscle 2019, 10, 323-337. [CrossRef]

46. Zhao, J.; Brault, J.J.; Schild, A.; Cao, P.; Sandri, M.; Schiaffino, S.; Lecker, S.H.; Goldberg, A.L. FoxO3 coordinately activates protein degradation by the autophagic/lysosomal and proteasomal pathways in atrophying muscle cells. Cell Metab. 2007, 6, 472-483. [CrossRef]

47. Mammucari, C.; Milan, G.; Romanello, V.; Masiero, E.; Rudolf, R.; Del Piccolo, P.; Burden, S.J.; Di Lisi, R.; Sandri, C.; Zhao, J.; et al. FoxO3 controls autophagy in skeletal muscle in vivo. Cell Metab. 2007, 6, 458-471. [CrossRef]

48. Ju, J.-S.; Fuentealba, R.A.; Miller, S.E.; Jackson, E.; Piwnica-Worms, D.; Baloh, R.H.; Weihl, C.C. Valosin-containing protein (VCP) is required for autophagy and is disrupted in VCP disease. J. Cell Biol. 2009, 187, 875-888. [CrossRef]

49. Kustermann, M.; Manta, L.; Paone, C.; Kustermann, J.; Lausser, L.; Wiesner, C.; Eichinger, L.; Clemen, C.S.; Schröder, R.; Kestler, H.A.; et al. Loss of the novel Vcp (valosin containing protein) interactor Washc4 interferes with autophagy-mediated proteostasis in striated muscle and leads to myopathy in vivo. Autophagy 2018, 14, 1911-1927. [CrossRef]

50. Piccirillo, R.; Goldberg, A.L. The p97/VCP ATPase is critical in muscle atrophy and the accelerated degradation of muscle proteins. EMBO J. 2012, 31, 3334-3350. [CrossRef]

51. Volodin, A.; Kosti, I.; Goldberg, A.L.; Cohen, S. Myofibril breakdown during atrophy is a delayed response requiring the transcription factor PAX4 and desmin depolymerization. Proc. Natl. Acad. Sci. USA 2017, 114, E1375-E1384. [CrossRef] [PubMed] 
52. Raffaello, A.; Milan, G.; Masiero, E.; Carnio, S.; Lee, D.; Lanfranchi, G.; Goldberg, A.L.; Sandri, M. JunB transcription factor maintains skeletal muscle mass and promotes hypertrophy. J. Cell Biol. 2010, 191, 101-113. [CrossRef] [PubMed]

53. Freire, P.P.; Fernandez, G.J.; Cury, S.S.; de Moraes, D.; Oliveira, J.S.; de Oliveira, G.; Dal-Pai-Silva, M.; Dos Reis, P.P.; Carvalho, R.F. The Pathway to Cancer Cachexia: MicroRNA-Regulated Networks in Muscle Wasting Based on Integrative Meta-Analysis. Int. J. Mol. Sci. 2019, 20, 1962. [CrossRef] [PubMed]

54. Piccirillo, R.; Demontis, F.; Perrimon, N.; Goldberg, A.L. Mechanisms of muscle growth and atrophy in mammals and Drosophila. Dev. Dyn. 2014, 243, 201-215. [CrossRef] [PubMed]

55. Smith, K.L.; Tisdale, M.J. Increased protein degradation and decreased protein synthesis in skeletal muscle during cancer cachexia. Br. J. Cancer 1993, 67, 680-685. [CrossRef]

56. Brown, J.L.; Lee, D.E.; Rosa-Caldwell, M.E.; Brown, L.A.; Perry, R.A.; Haynie, W.S.; Huseman, K.; Sataranatarajan, K.; Van Remmen, H.; Washington, T.A.; et al. Protein imbalance in the development of skeletal muscle wasting in tumour-bearing mice. J. Cachexia Sarcopenia Muscle 2018, 9, 987-1002. [CrossRef]

57. Baracos, V.E.; Mazurak, V.C.; Bhullar, A.S. Cancer cachexia is defined by an ongoing loss of skeletal muscle mass. Ann. Palliat. Med. 2019, 8, 3-12. [CrossRef]

58. Lagirand-Cantaloube, J.; Offner, N.; Csibi, A.; Leibovitch, M.P.; Batonnet-Pichon, S.; Tintignac, L.A.; Segura, C.T.; Leibovitch, S.A. The initiation factor eIF3-f is a major target for atrogin1/MAFbx function in skeletal muscle atrophy. EMBO J. 2008, 27, 1266-1276. [CrossRef]

59. Shi, J.; Luo, L.; Eash, J.; Ibebunjo, C.; Glass, D.J. The SCF-Fbxo40 complex induces IRS1 ubiquitination in skeletal muscle, limiting IGF1 signaling. Dev. Cell 2011, 21, 835-847. [CrossRef]

60. Terawaki, K.; Sawada, Y.; Kashiwase, Y.; Hashimoto, H.; Yoshimura, M.; Suzuki, M.; Miyano, K.; Sudo, Y.; Shiraishi, S.; Higami, Y.; et al. New cancer cachexia rat model generated by implantation of a peritoneal dissemination-derived human stomach cancer cell line. Am. J. Physiol. Endocrinol. Metab. 2014, 306, E373-E387. [CrossRef]

61. Norton, J.A.; Moley, J.F.; Green, M.V.; Carson, R.E.; Morrison, S.D. Parabiotic transfer of cancer anorexia/cachexia in male rats. Cancer Res. 1985, 45, 5547-5552. [PubMed]

62. Tomasin, R.; Martin, A.C.B.M.; Cominetti, M.R. Metastasis and cachexia: Alongside in clinics, but not so in animal models. J. Cachexia Sarcopenia Muscle 2019, 10, 1183-1194. [CrossRef] [PubMed]

63. Porporato, P.E. Understanding cachexia as a cancer metabolism syndrome. Oncogenesis 2016, 5, e200. [CrossRef] [PubMed]

64. Liva, S.G.; Tseng, Y.-C.; Dauki, A.M.; Sovic, M.G.; Vu, T.; Henderson, S.E.; Kuo, Y.-C.; Benedict, J.A.; Zhang, X.; Remaily, B.C.; et al. Overcoming resistance to anabolic SARM therapy in experimental cancer cachexia with an HDAC inhibitor. EMBO Mol. Med. 2020, 12, e9910. [CrossRef]

65. Antoun, S.; Raynard, B. Muscle protein anabolism in advanced cancer patients: Response to protein and amino acids support, and to physical activity. Ann. Oncol. 2018, 29, ii10-ii17. [CrossRef]

66. Lin, J.; Handschin, C.; Spiegelman, B.M. Metabolic control through the PGC-1 family of transcription coactivators. Cell Metab. 2005, 1, 361-370. [CrossRef]

67. Joseph, A.-M.; Adhihetty, P.J.; Leeuwenburgh, C. Beneficial effects of exercise on age-related mitochondrial dysfunction and oxidative stress in skeletal muscle. J. Physiol. 2016, 594, 5105-5123. [CrossRef]

68. Sandri, M.; Lin, J.; Handschin, C.; Yang, W.; Arany, Z.P.; Lecker, S.H.; Goldberg, A.L.; Spiegelman, B.M. PGC-1alpha protects skeletal muscle from atrophy by suppressing FoxO3 action and atrophy-specific gene transcription. Proc. Natl. Acad. Sci. USA 2006, 103, 16260-16265. [CrossRef]

69. Brault, J.J.; Jespersen, J.G.; Goldberg, A.L. Peroxisome proliferator-activated receptor gamma coactivator 1alpha or 1beta overexpression inhibits muscle protein degradation, induction of ubiquitin ligases, and disuse atrophy. J. Biol. Chem. 2010, 285, 19460-19471. [CrossRef]

70. Re Cecconi, A.D.; Forti, M.; Chiappa, M.; Zhu, Z.; Zingman, L.V.; Cervo, L.; Beltrame, L.; Marchini, S.; Piccirillo, R. Musclin, A Myokine Induced by Aerobic Exercise, Retards Muscle Atrophy During Cancer Cachexia in Mice. Cancers 2019, 11, 1541. [CrossRef]

71. Boström, P.; Wu, J.; Jedrychowski, M.P.; Korde, A.; Ye, L.; Lo, J.C.; Rasbach, K.A.; Boström, E.A.; Choi, J.H.; Long, J.Z.; et al. A PGC1- $\alpha$-dependent myokine that drives brown-fat-like development of white fat and thermogenesis. Nature 2012, 481, 463-468. [CrossRef] [PubMed]

72. Jones, D.P. Redefining oxidative stress. Antioxid. Redox Signal. 2006, 8, 1865-1879. [CrossRef] [PubMed] 
73. Halliwell, B.; Whiteman, M. Measuring reactive species and oxidative damage in vivo and in cell culture: How should you do it and what do the results mean? Br. J. Pharmacol. 2004, 142, 231-255. [CrossRef] [PubMed]

74. Biswas, S.K. Does the Interdependence between Oxidative Stress and Inflammation Explain the Antioxidant Paradox? Oxid. Med. Cell Longev. 2016, 2016, 5698931. [CrossRef] [PubMed]

75. Ruttkay-Nedecky, B.; Nejdl, L.; Gumulec, J.; Zitka, O.; Masarik, M.; Eckschlager, T.; Stiborova, M.; Adam, V.; Kizek, R. The role of metallothionein in oxidative stress. Int. J. Mol. Sci. 2013, 14, 6044-6066. [CrossRef]

76. Harding, H.P.; Zhang, Y.; Zeng, H.; Novoa, I.; Lu, P.D.; Calfon, M.; Sadri, N.; Yun, C.; Popko, B.; Paules, R.; et al. An integrated stress response regulates amino acid metabolism and resistance to oxidative stress. Mol. Cell 2003, 11, 619-633. [CrossRef]

77. Chan, K.; Han, X.D.; Kan, Y.W. An important function of Nrf2 in combating oxidative stress: Detoxification of acetaminophen. Proc. Natl. Acad. Sci. USA 2001, 98, 4611-4616. [CrossRef]

78. Milan, G.; Romanello, V.; Pescatore, F.; Armani, A.; Paik, J.-H.; Frasson, L.; Seydel, A.; Zhao, J.; Abraham, R.; Goldberg, A.L.; et al. Regulation of autophagy and the ubiquitin-proteasome system by the FoxO transcriptional network during muscle atrophy. Nat. Commun. 2015, 6, 6670. [CrossRef]

79. Xiao, Y.; Karam, C.; Yi, J.; Zhang, L.; Li, X.; Yoon, D.; Wang, H.; Dhakal, K.; Ramlow, P.; Yu, T.; et al. ROS-related mitochondrial dysfunction in skeletal muscle of an ALS mouse model during the disease progression. Pharmacol. Res. 2018, 138, 25-36. [CrossRef]

80. Connolly, O.; Le Gall, L.; McCluskey, G.; Donaghy, C.G.; Duddy, W.J.; Duguez, S. A Systematic Review of Genotype-Phenotype Correlation across Cohorts Having Causal Mutations of Different Genes in ALS. J. Pers. Med. 2020, 10, 58. [CrossRef]

81. Brown, J.L.; Lawrence, M.M.; Ahn, B.; Kneis, P.; Piekarz, K.M.; Qaisar, R.; Ranjit, R.; Bian, J.; Pharaoh, G.; Brown, C.; et al. Cancer cachexia in a mouse model of oxidative stress. J. Cachexia Sarcopenia Muscle 2020. [CrossRef] [PubMed]

82. Summermatter, S.; Bouzan, A.; Pierrel, E.; Melly, S.; Stauffer, D.; Gutzwiller, S.; Nolin, E.; Dornelas, C.; Fryer, C.; Leighton-Davies, J.; et al. Blockade of Metallothioneins 1 and 2 Increases Skeletal Muscle Mass and Strength. Mol. Cell. Biol. 2017, 37. [CrossRef] [PubMed]

83. Russell, S.T.; Siren, P.M.A.; Siren, M.J.; Tisdale, M.J. The role of zinc in the anti-tumour and anti-cachectic activity of D-myo-inositol 1,2,6-triphosphate. Br. J. Cancer 2010, 102, 833-836. [CrossRef] [PubMed]

84. Ballarò, R.; Beltrà, M.; De Lucia, S.; Pin, F.; Ranjbar, K.; Hulmi, J.J.; Costelli, P.; Penna, F. Moderate exercise in mice improves cancer plus chemotherapy-induced muscle wasting and mitochondrial alterations. FASEB J. 2019, 33, 5482-5494. [CrossRef] [PubMed]

85. Assi, M.; Derbré, F.; Lefeuvre-Orfila, L.; Rébillard, A. Antioxidant supplementation accelerates cachexia development by promoting tumor growth in C26 tumor-bearing mice. Free Radic. Biol. Med. 2016, 91, 204-214. [CrossRef] [PubMed]

86. Abrigo, J.; Rivera, J.C.; Simon, F.; Cabrera, D.; Cabello-Verrugio, C. Transforming growth factor type beta (TGF- $\beta$ ) requires reactive oxygen species to induce skeletal muscle atrophy. Cell Signal. 2016, 28, 366-376. [CrossRef] [PubMed]

87. Li, Y.P.; Schwartz, R.J.; Waddell, I.D.; Holloway, B.R.; Reid, M.B. Skeletal muscle myocytes undergo protein loss and reactive oxygen-mediated NF-kappaB activation in response to tumor necrosis factor alpha. FASEB J. 1998, 12, 871-880. [CrossRef]

88. Buck, M.; Chojkier, M. Muscle wasting and dedifferentiation induced by oxidative stress in a murine model of cachexia is prevented by inhibitors of nitric oxide synthesis and antioxidants. EMBO J. 1996, 15, 1753-1765. [CrossRef]

89. Roy, A.; Sharma, A.K.; Nellore, K.; Narkar, V.A.; Kumar, A. TAK1 preserves skeletal muscle mass and mitochondrial function through redox homeostasis. FASEB Bioadv. 2020, 2, 538-553. [CrossRef]

90. Lenk, K.; Schuler, G.; Adams, V. Skeletal muscle wasting in cachexia and sarcopenia: Molecular pathophysiology and impact of exercise training. J. Cachexia Sarcopenia Muscle 2010, 1, 9-21. [CrossRef]

91. Sanders, P.M.; Russell, S.T.; Tisdale, M.J. Angiotensin II directly induces muscle protein catabolism through the ubiquitin-proteasome proteolytic pathway and may play a role in cancer cachexia. Br. J. Cancer 2005, 93, 425-434. [CrossRef] [PubMed] 
92. Leitner, L.M.; Wilson, R.J.; Yan, Z.; Gödecke, A. Reactive Oxygen Species/Nitric Oxide Mediated Inter-Organ Communication in Skeletal Muscle Wasting Diseases. Antioxid Redox Signal. 2017, 26, 700-717. [CrossRef] [PubMed]

93. Sullivan-Gunn, M.J.; Campbell-O'Sullivan, S.P.; Tisdale, M.J.; Lewandowski, P.A. Decreased NADPH oxidase expression and antioxidant activity in cachectic skeletal muscle. J. Cachexia Sarcopenia Muscle 2011, 2, 181-188. [CrossRef] [PubMed]

94. Brzeszczyńska, J.; Johns, N.; Schilb, A.; Degen, S.; Degen, M.; Langen, R.; Schols, A.; Glass, D.J.; Roubenoff, R.; Greig, C.A.; et al. Loss of oxidative defense and potential blockade of satellite cell maturation in the skeletal muscle of patients with cancer but not in the healthy elderly. Aging 2016, 8, 1690-1702. [CrossRef]

95. Musci, R.V.; Hamilton, K.L.; Linden, M.A. Exercise-Induced Mitohormesis for the Maintenance of Skeletal Muscle and Healthspan Extension. Sports 2019, 7, 170. [CrossRef]

96. Tan, P.L.; Shavlakadze, T.; Grounds, M.D.; Arthur, P.G. Differential thiol oxidation of the signaling proteins Akt, PTEN or PP2A determines whether Akt phosphorylation is enhanced or inhibited by oxidative stress in C2C12 myotubes derived from skeletal muscle. Int. J. Biochem. Cell Biol. 2015, 62, 72-79. [CrossRef]

97. Aucello, M.; Dobrowolny, G.; Musarò, A. Localized accumulation of oxidative stress causes muscle atrophy through activation of an autophagic pathway. Autophagy 2009, 5, 527-529. [CrossRef]

98. Barreiro, E.; de la Puente, B.; Busquets, S.; López-Soriano, F.J.; Gea, J.; Argilés, J.M. Both oxidative and nitrosative stress are associated with muscle wasting in tumour-bearing rats. FEBS Lett. 2005, 579, 1646-1652. [CrossRef]

99. Mantovani, G.; Macciò, A.; Madeddu, C.; Mura, L.; Gramignano, G.; Lusso, M.R.; Massa, E.; Mocci, M.; Serpe, R. Antioxidant agents are effective in inducing lymphocyte progression through cell cycle in advanced cancer patients: Assessment of the most important laboratory indexes of cachexia and oxidative stress. J. Mol. Med. 2003, 81, 664-673. [CrossRef]

100. Banks, W.A.; Kastin, A.J.; Durham, D.A. Bidirectional transport of interleukin-1 alpha across the blood-brain barrier. Brain Res. Bull. 1989, 23, 433-437. [CrossRef]

101. Banks, W.A.; Kastin, A.J.; Ehrensing, C.A. Blood-borne interleukin-1 alpha is transported across the endothelial blood-spinal cord barrier of mice. J. Physiol. 1994, 479, 257-264. [CrossRef] [PubMed]

102. Pan, W.; Yu, C.; Hsuchou, H.; Zhang, Y.; Kastin, A.J. Neuroinflammation facilitates LIF entry into brain: Role of TNF. Am. J. Physiol. Cell Physiol. 2008, 294, C1436-C1442. [CrossRef] [PubMed]

103. Banks, W.A.; Kastin, A.J.; Gutierrez, E.G. Penetration of interleukin-6 across the murine blood-brain barrier. Neurosci. Lett. 1994, 179, 53-56. [CrossRef]

104. Laviano, A.; Meguid, M.M.; Preziosa, I.; Rossi Fanelli, F. Oxidative stress and wasting in cancer. Curr Opin Clin. Nutr. Metab. Care 2007, 10, 449-456. [CrossRef] [PubMed]

105. Negri, D.R.; Mezzanzanica, D.; Sacco, S.; Gadina, M.; Benigni, F.; Cajola, L.; Finocchiaro, G.; Ghezzi, P.; Canevari, S. Role of cytokines in cancer cachexia in a murine model of intracerebral injection of human tumours. Cytokine 2001, 15, 27-38. [CrossRef]

106. Plata-Salamán, C.R.; Sonti, G.; Borkoski, J.P.; Wilson, C.D. French-Mullen JM 04189@brahmsudeledu, null Anorexia induced by chronic central administration of cytokines at estimated pathophysiological concentrations. Physiol. Behav. 1996, 60, 867-875.

107. Heber, D.; Li, Z. Nutrition Intervention in Cancer. Med. Clin. North. Am. 2016, 100, 1329-1340. [CrossRef]

108. Argilés, J.M. Cancer-associated malnutrition. Eur. J. Oncol. Nurs. 2005, 9 (Suppl 2), S39-S50. [CrossRef]

109. Koshimoto, S.; Arimoto, M.; Saitou, K.; Uchibori, M.; Hashizume, A.; Honda, A.; Amano, K.; Nakajima, Y.; Uetake, H.; Matsushima, E. Need and demand for nutritional counselling and their association with quality of life, nutritional status and eating-related distress among patients with cancer receiving outpatient chemotherapy: A cross-sectional study. Support. Care Cancer 2019, 27, 3385-3394. [CrossRef]

110. Ravasco, P. Nutritional approaches in cancer: Relevance of individualized counseling and supplementation. Nutrition 2015, 31, 603-604. [CrossRef]

111. Bauer, J. Nutritional Management and Dietary Guidelines for Cancer Cachexia. Eur. Oncol. Haematol. 2007, 1, 12-14. [CrossRef]

112. Burden, S.; Jones, D.J.; Sremanakova, J.; Sowerbutts, A.M.; Lal, S.; Pilling, M.; Todd, C. Dietary interventions for adult cancer survivors. Cochrane Database Syst. Rev. 2019, 2019. [CrossRef] 
113. Uster, A.; Ruefenacht, U.; Ruehlin, M.; Pless, M.; Siano, M.; Haefner, M.; Imoberdorf, R.; Ballmer, P.E. Influence of a nutritional intervention on dietary intake and quality of life in cancer patients: A randomized controlled trial. Nutrition 2013, 29, 1342-1349. [CrossRef] [PubMed]

114. Bourdel-Marchasson, I.; Blanc-Bisson, C.; Doussau, A.; Germain, C.; Blanc, J.-F.; Dauba, J.; Lahmar, C.; Terrebonne, E.; Lecaille, C.; Ceccaldi, J.; et al. Nutritional advice in older patients at risk of malnutrition during treatment for chemotherapy: A two-year randomized controlled trial. PLoS ONE 2014, 9, e108687. [CrossRef] [PubMed]

115. Zhang, F.; Jin, Y.; Qiang, W. The effects of dietary advice on malnutrition in Cancer patients: A systematic review and meta-analysis. Support. Care Cancer 2020, 28, 1579-1585. [CrossRef] [PubMed]

116. Palesty, J.A.; Dudrick, S.J. Cachexia, malnutrition, the refeeding syndrome, and lessons from Goldilocks. Surg. Clin. North. Am. 2011, 91, 653-673. [CrossRef] [PubMed]

117. Khan, L.U.R.; Ahmed, J.; Khan, S.; Macfie, J. Refeeding syndrome: A literature review. Gastroenterol. Res. Pract. 2011, 2011. [CrossRef] [PubMed]

118. Del Fabbro, E.; Hui, D.; Dalal, S.; Dev, R.; Nooruddin, Z.I.; Noorhuddin, Z.; Bruera, E. Clinical outcomes and contributors to weight loss in a cancer cachexia clinic. J. Palliat. Med. 2011, 14, 1004-1008. [CrossRef]

119. Olson, B.; Marks, D.L.; Grossberg, A.J. Diverging metabolic programmes and behaviours during states of starvation, protein malnutrition, and cachexia. J. Cachexia Sarcopenia Muscle 2020. [CrossRef]

120. Mori, T.; Ohmori, H.; Luo, Y.; Mori, S.; Miyagawa, Y.; Nukaga, S.; Goto, K.; Fujiwara-Tani, R.; Kishi, S.; Sasaki, T.; et al. Giving combined medium-chain fatty acids and glucose protects against cancer-associated skeletal muscle atrophy. Cancer Sci. 2019, 110, 3391-3399. [CrossRef]

121. Tan, B.L.; Norhaizan, M.E. Oxidative Stress, Diet and Prostate Cancer. World J. Mens Health 2020, 38. [CrossRef] [PubMed]

122. Arcidiacono, B.; Iiritano, S.; Nocera, A.; Possidente, K.; Nevolo, M.T.; Ventura, V.; Foti, D.; Chiefari, E.; Brunetti, A. Insulin resistance and cancer risk: An overview of the pathogenetic mechanisms. Exp. Diabetes Res. 2012, 2012, 789174. [CrossRef] [PubMed]

123. Maurizi, G.; Della Guardia, L.; Maurizi, A.; Poloni, A. Adipocytes properties and crosstalk with immune system in obesity-related inflammation. J. Cell Physiol. 2018, 233, 88-97. [CrossRef] [PubMed]

124. Hernáandez, J.; Syed, S.; Weiss, G.; Fernandes, G.; von Merveldt, D.; Troyer, D.A.; Basler, J.W.; Thompson, I.M. The modulation of prostate cancer risk with alpha-tocopherol: A pilot randomized, controlled clinical trial. J. Urol. 2005, 174, 519-522. [CrossRef] [PubMed]

125. Kyriakopoulos, C.E.; Heath, E.I.; Eickhoff, J.C.; Kolesar, J.; Yayehyirad, M.; Moll, T.; Wilding, G.; Liu, G. A multicenter phase $1 / 2$ a dose-escalation study of the antioxidant moiety of vitamin $\mathrm{E}$ 2,2,5,7,8-pentamethyl-6-chromanol (APC-100) in men with advanced prostate cancer. Invest. New Drugs 2016, 34, 225-230. [CrossRef]

126. Allen, N.E.; Travis, R.C.; Appleby, P.N.; Albanes, D.; Barnett, M.J.; Black, A.; Bueno-de-Mesquita, H.B.; Deschasaux, M.; Galan, P.; Goodman, G.E.; et al. Selenium and Prostate Cancer: Analysis of Individual Participant Data From Fifteen Prospective Studies. J. Natl. Cancer Inst. 2016, 108. [CrossRef]

127. Baldwin, C.; Spiro, A.; Ahern, R.; Emery, P.W. Oral nutritional interventions in malnourished patients with cancer: A systematic review and meta-analysis. J. Natl. Cancer Inst. 2012, 104, 371-385. [CrossRef]

128. Balstad, T.R.; Solheim, T.S.; Strasser, F.; Kaasa, S.; Bye, A. Dietary treatment of weight loss in patients with advanced cancer and cachexia: A systematic literature review. Crit. Rev. Oncol. Hematol. 2014, 91, 210-221. [CrossRef]

129. de van der Schueren, M.A.E.; Laviano, A.; Blanchard, H.; Jourdan, M.; Arends, J.; Baracos, V.E. Systematic review and meta-analysis of the evidence for oral nutritional intervention on nutritional and clinical outcomes during chemo(radio)therapy: Current evidence and guidance for design of future trials. Ann. Oncol. 2018, 29, 1141-1153. [CrossRef]

130. Hasler, C.M. Functional Foods: Benefits, Concerns and Challenges-A Position Paper from the American Council on Science and Health. J. Nutr. 2002, 132, 3772-3781. [CrossRef]

131. Kalra, E.K. Nutraceutical-definition and introduction. AAPS PharmSci 2003, 5, E25. [CrossRef] [PubMed]

132. Aquila, G.; Marracino, L.; Martino, V.; Calabria, D.; Campo, G.; Caliceti, C.; Rizzo, P. The Use of Nutraceuticals to Counteract Atherosclerosis: The Role of the Notch Pathway. Oxid. Med. Cell. Longev. 2019, 2019, 1-30. [CrossRef] [PubMed] 
133. Ranzato, E.; Martinotti, S.; Calabrese, C.M.; Calabrese, G. Role of Nutraceuticals in Cancer Therapy. J. Food Res. 2014, 3, 18. [CrossRef]

134. Siriwardhana, N.; Kalupahana, N.S.; Moustaid-Moussa, N. Health benefits of $n-3$ polyunsaturated fatty acids: Eicosapentaenoic acid and docosahexaenoic acid. Adv. Food Nutr. Res. 2012, 65, 211-222. [CrossRef] [PubMed]

135. Moloudizargari, M.; Mortaz, E.; Asghari, M.H.; Adcock, I.M.; Redegeld, F.A.; Garssen, J. Effects of the polyunsaturated fatty acids, EPA and DHA, on hematological malignancies: A systematic review. Oncotarget 2018, 9, 11858-11875. [CrossRef]

136. Lee, J.Y.; Plakidas, A.; Lee, W.H.; Heikkinen, A.; Chanmugam, P.; Bray, G.; Hwang, D.H. Differential modulation of Toll-like receptors by fatty acids: Preferential inhibition by $n-3$ polyunsaturated fatty acids. J. Lipid Res. 2003, 44, 479-486. [CrossRef]

137. Kliewer, S.A.; Sundseth, S.S.; Jones, S.A.; Brown, P.J.; Wisely, G.B.; Koble, C.S.; Devchand, P.; Wahli, W.; Willson, T.M.; Lenhard, J.M.; et al. Fatty acids and eicosanoids regulate gene expression through direct interactions with peroxisome proliferator-activated receptors alpha and gamma. Proc. Natl. Acad. Sci. USA 1997, 94, 4318-4323. [CrossRef]

138. Oh, D.Y.; Talukdar, S.; Bae, E.J.; Imamura, T.; Morinaga, H.; Fan, W.; Li, P.; Lu, W.J.; Watkins, S.M.; Olefsky, J.M. GPR120 is an omega-3 fatty acid receptor mediating potent anti-inflammatory and insulin-sensitizing effects. Cell 2010, 142, 687-698. [CrossRef]

139. Zheng, Z.; Ge, Y.; Zhang, J.; Xue, M.; Li, Q.; Lin, D.; Ma, W. PUFA diets alter the microRNA expression profiles in an inflammation rat model. Mol. Med. Rep. 2015, 11, 4149-4157. [CrossRef]

140. Piffar, P.M.; Fernandez, R.; Tchaikovski, O.; Hirabara, S.M.; Folador, A.; Pinto, G.J.; Jakobi, S.; Gobbo-Bordon, D.; Rohn, T.V.; Fabrício, V.E.B.; et al. Naproxen, clenbuterol and insulin administration ameliorates cancer cachexia and reduce tumor growth in Walker 256 tumor-bearing rats. Cancer Lett. 2003, 201, 139-148. [CrossRef]

141. Ruud, J.; Nilsson, A.; Engström Ruud, L.; Wang, W.; Nilsberth, C.; Iresjö, B.-M.; Lundholm, K.; Engblom, D.; Blomqvist, A. Cancer-induced anorexia in tumor-bearing mice is dependent on cyclooxygenase-1. Brain Behav. Immun. 2013, 29, 124-135. [CrossRef] [PubMed]

142. Henriques, F.; Lopes, M.A.; Franco, F.O.; Knobl, P.; Santos, K.B.; Bueno, L.L.; Correa, V.A.; Bedard, A.H.; Guilherme, A.; Birbrair, A.; et al. Toll-Like Receptor-4 Disruption Suppresses Adipose Tissue Remodeling and Increases Survival in Cancer Cachexia Syndrome. Sci. Rep. 2018, 8, 18024. [CrossRef] [PubMed]

143. Murphy, R.A.; Yeung, E.; Mazurak, V.C.; Mourtzakis, M. Influence of eicosapentaenoic acid supplementation on lean body mass in cancer cachexia. Br. J. Cancer 2011, 105, 1469-1473. [CrossRef] [PubMed]

144. Colomer, R.; Moreno-Nogueira, J.M.; García-Luna, P.P.; García-Peris, P.; García-de-Lorenzo, A.; Zarazaga, A.; Quecedo, L.; del Llano, J.; Usán, L.; Casimiro, C. N-3 fatty acids, cancer and cachexia: A systematic review of the literature. Br. J. Nutr. 2007, 97, 823-831. [CrossRef] [PubMed]

145. McGlory, C.; Calder, P.C.; Nunes, E.A. The Influence of Omega-3 Fatty Acids on Skeletal Muscle Protein Turnover in Health, Disuse, and Disease. Front. Nutr. 2019, 6, 144. [CrossRef] [PubMed]

146. Freitas, R.D.S.; Campos, M.M. Protective Effects of Omega-3 Fatty Acids in Cancer-Related Complications. Nutrients 2019, 11, 945. [CrossRef] [PubMed]

147. Gorjao, R.; dos Santos, C.M.M.; Serdan, T.D.A.; Diniz, V.L.S.; Alba-Loureiro, T.C.; Cury-Boaventura, M.F.; Hatanaka, E.; Levada-Pires, A.C.; Sato, F.T.; Pithon-Curi, T.C.; et al. New insights on the regulation of cancer cachexia by N-3 polyunsaturated fatty acids. Pharmacol. Ther. 2019, 196, 117-134. [CrossRef]

148. Smith, H.J.; Lorite, M.J.; Tisdale, M.J. Effect of a cancer cachectic factor on protein synthesis/degradation in murine C2C12 myoblasts: Modulation by eicosapentaenoic acid. Cancer Res. 1999, 59, 5507-5513.

149. Wang, Y.; Lin, Q.; Zheng, P.; Zhang, J.; Huang, F. DHA inhibits protein degradation more efficiently than EPA by regulating the PPAR $\gamma / \mathrm{NFkB}$ pathway in C2C12 myotubes. BioMed Res. Int. 2013, 2013, 318981. [CrossRef]

150. Huang, F.; Wei, H.; Luo, H.; Jiang, S.; Peng, J. EPA inhibits the inhibitor of $\kappa \mathrm{B} \alpha(\mathrm{I} \kappa \mathrm{B} \alpha) / \mathrm{NF}-\kappa \mathrm{B} / \mathrm{muscle}$ RING finger 1 pathway in C2C12 myotubes in a PPAR $\gamma$-dependent manner. Br. J. Nutr. 2011, 105, 348-356. [CrossRef]

151. Kamolrat, T.; Gray, S.R. The effect of eicosapentaenoic and docosahexaenoic acid on protein synthesis and breakdown in murine C2C12 myotubes. Biochem. Biophys. Res. Commun. 2013, 432, 593-598. [CrossRef] [PubMed] 
152. Muzio, G.; Ricci, M.; Traverso, N.; Monacelli, F.; Oraldi, M.; Maggiora, M.; Canuto, R.A. 4-Hydroxyhexenal and 4-hydroxynonenal are mediators of the anti-cachectic effect of $n-3$ and n- 6 polyunsaturated fatty acids on human lung cancer cells. Free Radic. Biol. Med. 2016, 99, 63-70. [CrossRef] [PubMed]

153. Whitehouse, A.S.; Smith, H.J.; Drake, J.L.; Tisdale, M.J. Mechanism of attenuation of skeletal muscle protein catabolism in cancer cachexia by eicosapentaenoic acid. Cancer Res. 2001, 61, 3604-3609. [PubMed]

154. Tisdale, M.J. Inhibition of lipolysis and muscle protein degradation by EPA in cancer cachexia. Nutrition 1996, 12, S31-S33. [CrossRef]

155. Schiessel, D.L.; Yamazaki, R.K.; Kryczyk, M.; Coelho, I.; Yamaguchi, A.A.; Pequito, D.C.T.; Brito, G.A.P.; Borghetti, G.; Fernandes, L.C. $\alpha$-Linolenic Fatty Acid Supplementation Decreases Tumor Growth and Cachexia Parameters in Walker 256 Tumor-Bearing Rats. Nutr. Cancer 2015, 67, 839-846. [CrossRef]

156. Dijk, F.J.; van Dijk, M.; Dorresteijn, B.; van Norren, K. DPA shows comparable chemotherapy sensitizing effects as EPA upon cellular incorporation in tumor cells. Oncotarget 2019, 10, 5983-5992. [CrossRef]

157. Aquila, G.; Re Cecconi, A.D.; Forti, M.; Frapolli, R.; Bello, E.; Novelli, D.; Russo, I.; Licandro, S.A.; Staszewsky, L.; Martinelli, G.B.; et al. Trabectedin and Lurbinectedin Extend Survival of Mice Bearing C26 Colon Adenocarcinoma, without Affecting Tumor Growth or Cachexia. Cancers 2020, 12, 2312. [CrossRef]

158. Nissinen, T.A.; Hentilä, J.; Penna, F.; Lampinen, A.; Lautaoja, J.H.; Fachada, V.; Holopainen, T.; Ritvos, O.; Kivelä, R.; Hulmi, J.J. Treating cachexia using soluble ACVR2B improves survival, alters mTOR localization, and attenuates liver and spleen responses: Treating cachexia using soluble ACVR2B. J. Cachexia Sarcopenia Muscle 2018, 9, 514-529. [CrossRef]

159. van Norren, K.; Kegler, D.; Argilés, J.M.; Luiking, Y.; Gorselink, M.; Laviano, A.; Arts, K.; Faber, J.; Jansen, H.; van der Beek, E.M.; et al. Dietary supplementation with a specific combination of high protein, leucine, and fish oil improves muscle function and daily activity in tumour-bearing cachectic mice. Br. J. Cancer 2009, 100, 713-722. [CrossRef]

160. Faber, J.; Vos, P.; Kegler, D.; van Norren, K.; Argilés, J.M.; Laviano, A.; Garssen, J.; van Helvoort, A. Beneficial immune modulatory effects of a specific nutritional combination in a murine model for cancer cachexia. Br. J. Cancer 2008, 99, 2029-2036. [CrossRef]

161. Pappalardo, G.; Almeida, A.; Ravasco, P. Eicosapentaenoic acid in cancer improves body composition and modulates metabolism. Nutrition 2015, 31, 549-555. [CrossRef] [PubMed]

162. Mazzotta, P.; Jeney, C.M. Anorexia-cachexia syndrome: A systematic review of the role of dietary polyunsaturated Fatty acids in the management of symptoms, survival, and quality of life. J. Pain Symptom Manag. 2009, 37, 1069-1077. [CrossRef] [PubMed]

163. Lavriv, D.S.; Neves, P.M.; Ravasco, P. Should omega-3 fatty acids be used for adjuvant treatment of cancer cachexia? Clin. Nutr. ESPEN 2018, 25, 18-25. [CrossRef] [PubMed]

164. Sakai, C.; Ishida, M.; Ohba, H.; Yamashita, H.; Uchida, H.; Yoshizumi, M.; Ishida, T. Fish oil omega-3 polyunsaturated fatty acids attenuate oxidative stress-induced DNA damage in vascular endothelial cells. PLOS ONE 2017, 12, e0187934. [CrossRef]

165. Kusunoki, C.; Yang, L.; Yoshizaki, T.; Nakagawa, F.; Ishikado, A.; Kondo, M.; Morino, K.; Sekine, O.; Ugi, S.; Nishio, Y.; et al. Omega-3 polyunsaturated fatty acid has an anti-oxidant effect via the Nrf-2/HO-1 pathway in 3T3-L1 adipocytes. Biochem. Biophys. Res. Commun. 2013, 430, 225-230. [CrossRef]

166. Zhang, M.; Wang, S.; Mao, L.; Leak, R.K.; Shi, Y.; Zhang, W.; Hu, X.; Sun, B.; Cao, G.; Gao, Y.; et al. Omega-3 fatty acids protect the brain against ischemic injury by activating Nrf2 and upregulating heme oxygenase 1. J. Neurosci. 2014, 34, 1903-1915. [CrossRef]

167. Farías, J.G.; Carrasco-Pozo, C.; Carrasco Loza, R.; Sepúlveda, N.; Álvarez, P.; Quezada, M.; Quiñones, J.; Molina, V.; Castillo, R.L. Polyunsaturated fatty acid induces cardioprotection against ischemia-reperfusion through the inhibition of NF-kappaB and induction of Nrf2. Exp. Biol. Med. 2017, 242, 1104-1114. [CrossRef]

168. Schwartz, S.A.; Hernandez, A.; Mark Evers, B. The role of NF-kappaB/IkappaB proteins in cancer: Implications for novel treatment strategies. Surg Oncol 1999, 8, 143-153. [CrossRef]

169. Siddiqui, R.A.; Harvey, K.; Stillwell, W. Anticancer properties of oxidation products of docosahexaenoic acid. Chem. Phys. Lipids 2008, 153, 47-56. [CrossRef]

170. Ogunbileje, J.O.; Porter, C.; Herndon, D.N.; Chao, T.; Abdelrahman, D.R.; Papadimitriou, A.; Chondronikola, M.; Zimmers, T.A.; Reidy, P.T.; Rasmussen, B.B.; et al. Hypermetabolism and hypercatabolism of skeletal muscle accompany mitochondrial stress following severe burn trauma. Am. J. Physiol. Endocrinol. Metab. 2016, 311, E436-E448. [CrossRef] 
171. Ma, Y.-J.; Yu, J.; Xiao, J.; Cao, B.-W. The consumption of omega-3 polyunsaturated fatty acids improves clinical outcomes and prognosis in pancreatic cancer patients: A systematic evaluation. Nutr. Cancer 2015, 67, 112-118. [CrossRef] [PubMed]

172. Fukawa, T.; Yan-Jiang, B.C.; Min-Wen, J.C.; Jun-Hao, E.T.; Huang, D.; Qian, C.-N.; Ong, P.; Li, Z.; Chen, S.; Mak, S.Y.; et al. Excessive fatty acid oxidation induces muscle atrophy in cancer cachexia. Nature Med. 2016, 22, 666-671. [CrossRef] [PubMed]

173. Illingworth, D.R.; Connor, W.E.; Harris, W.S. Hypolipidemic effects of dietary omega-3 fatty acids in humans. Prog. Clin. Biol. Res. 1988, 255, 243-253. [PubMed]

174. Busquets, S.; Almendro, V.; Barreiro, E.; Figueras, M.; Argilés, J.M.; López-Soriano, F.J. Activation of UCPs gene expression in skeletal muscle can be independent on both circulating fatty acids and food intake. Involvement of ROS in a model of mouse cancer cachexia. FEBS Lett. 2005, 579, 717-722. [CrossRef]

175. Bing, C.; Brown, M.; King, P.; Collins, P.; Tisdale, M.J.; Williams, G. Increased gene expression of brown fat uncoupling protein (UCP)1 and skeletal muscle UCP2 and UCP3 in MAC16-induced cancer cachexia. Cancer Res. 2000, 60, 2405-2410.

176. Sanchís, D.; Busquets, S.; Alvarez, B.; Ricquier, D.; López-Soriano, F.J.; Argilés, J.M. Skeletal muscle UCP2 and UCP3 gene expression in a rat cancer cachexia model. FEBS Lett. 1998, 436, 415-418. [CrossRef]

177. Collins, P.; Bing, C.; McCulloch, P.; Williams, G. Muscle UCP-3 mRNA levels are elevated in weight loss associated with gastrointestinal adenocarcinoma in humans. Br. J. Cancer 2002, 86, 372-375. [CrossRef]

178. Brand, M.D.; Esteves, T.C. Physiological functions of the mitochondrial uncoupling proteins UCP2 and UCP3. Cell Metab. 2005, 2, 85-93. [CrossRef]

179. dos Reis Riccardi, D.M.; das Neves, R.X.; de Matos-Neto, E.M.; Camargo, R.G.; Lima, J.D.C.C.; Radloff, K.; Alves, M.J.; Costa, R.G.F.; Tokeshi, F.; Otoch, J.P.; et al. Plasma Lipid Profile and Systemic Inflammation in Patients With Cancer Cachexia. Front. Nutr. 2020, 7. [CrossRef]

180. Singer, P.; Wirth, M.; Berger, I. A possible contribution of decrease in free fatty acids to low serum triglyceride levels after diets supplemented with n-6 and n-3 polyunsaturated fatty acids. Atherosclerosis 1990, 83, 167-175. [CrossRef]

181. Cory, H.; Passarelli, S.; Szeto, J.; Tamez, M.; Mattei, J. The Role of Polyphenols in Human Health and Food Systems: A Mini-Review. Front. Nutr. 2018, 5, 87. [CrossRef] [PubMed]

182. Mileo, A.M.; Miccadei, S. Polyphenols as Modulator of Oxidative Stress in Cancer Disease: New Therapeutic Strategies. Oxid. Med. Cell. Longev. 2016, 2016, 6475624. [CrossRef] [PubMed]

183. Cheng, Y.-C.; Sheen, J.-M.; Hu, W.L.; Hung, Y.-C. Polyphenols and Oxidative Stress in Atherosclerosis-Related Ischemic Heart Disease and Stroke. Oxid. Med. Cell. Longev. 2017, 2017, 1-16. [CrossRef]

184. Mirza, K.A.; Pereira, S.L.; Edens, N.K.; Tisdale, M.J. Attenuation of muscle wasting in murine C2C 12 myotubes by epigallocatechin-3-gallate. J. Cachexia Sarcopenia Muscle 2014, 5, 339-345. [CrossRef] [PubMed]

185. Saimithra, T.; Kumar, N.; Nandakumar, K.; Nampoothiri, M.; Rao, C.M. Catechin, an active constituent of green tea, preserves skeletal muscle activity in dexamethasone induced cachexia by increasing acetylcholine sensitivity in muscles of wistar rats. Indian J. Exp. Biol. 2018, 56, 314-321.

186. Wang, H.; Lai, Y.-J.; Chan, Y.-L.; Li, T.-L.; Wu, C.-J. Epigallocatechin-3-gallate effectively attenuates skeletal muscle atrophy caused by cancer cachexia. Cancer Lett. 2011, 305, 40-49. [CrossRef]

187. Lecumberri, E.; Dupertuis, Y.M.; Miralbell, R.; Pichard, C. Green tea polyphenol epigallocatechin-3-gallate (EGCG) as adjuvant in cancer therapy. Clin. Nutr. 2013, 32, 894-903. [CrossRef]

188. Baba, Y.; Sonoda, J.-I.; Hayashi, S.; Tosuji, N.; Sonoda, S.; Makisumi, K.; Nakajo, M. Reduction of oxidative stress in liver cancer patients by oral green tea polyphenol tablets during hepatic arterial infusion chemotherapy. Exp. Ther. Med. 2012, 4, 452-458. [CrossRef]

189. Li, C.; Miao, X.; Li, F.; Adhikari, B.K.; Liu, Y.; Sun, J.; Zhang, R.; Cai, L.; Liu, Q.; Wang, Y. Curcuminoids: Implication for inflammation and oxidative stress in cardiovascular diseases. Phytother. Res. 2019, 33, 1302-1317. [CrossRef]

190. Si, H.; Wang, X.; Zhang, L.; Parnell, L.D.; Admed, B.; LeRoith, T.; Ansah, T.-A.; Zhang, L.; Li, J.; Ordovás, J.M.; et al. Dietary epicatechin improves survival and delays skeletal muscle degeneration in aged mice. FASEB J. 2019, 33, 965-977. [CrossRef] 
191. Zhou, L.; Mei, X.-Y. [Study on preventive and therapeutic effects of astragali radix on denervated tibial muscle atrophy in rats]. Zhongguo Zhong Yao Za Zhi 2014, 39, 1083-1087. (In Chinese) [PubMed]

192. Nakamura, K.; Nakano, S.-I.; Miyoshi, T.; Yamanouchi, K.; Nishihara, M. Loss of SPARC in mouse skeletal muscle causes myofiber atrophy. Muscle Nerve 2013, 48, 791-799. [CrossRef] [PubMed]

193. Catoire, M.; Mensink, M.; Kalkhoven, E.; Schrauwen, P.; Kersten, S. Identification of human exercise-induced myokines using secretome analysis. Physiol. Genom. 2014, 46, 256-267. [CrossRef] [PubMed]

194. Robinson, M.M.; Dasari, S.; Konopka, A.R.; Johnson, M.L.; Manjunatha, S.; Esponda, R.R.; Carter, R.E.; Lanza, I.R.; Nair, K.S. Enhanced Protein Translation Underlies Improved Metabolic and Physical Adaptations to Different Exercise Training Modes in Young and Old Humans. Cell Metab. 2017, 25, 581-592. [CrossRef] [PubMed]

195. Oelkrug, C.; Horn, K.; Makert, G.R.; Schubert, A. Novel in vitro platform to investigate myotube atrophy. Anticancer Res. 2015, 35, 2085-2091.

196. Oelkrug, C.; Lange, C.M.; Wenzel, E.; Fricke, S.; Hartke, M.; Simasi, J.; Schubert, A. Analysis of the tumoricidal and anti-cachectic potential of curcumin. Anticancer Res. 2014, 34, 4781-4788.

197. Wyke, S.M.; Russell, S.T.; Tisdale, M.J. Induction of proteasome expression in skeletal muscle is attenuated by inhibitors of NF-kappaB activation. Br. J. Cancer 2004, 91, 1742-1750. [CrossRef]

198. Siddiqui, R.A.; Hassan, S.; Harvey, K.A.; Rasool, T.; Das, T.; Mukerji, P.; DeMichele, S. Attenuation of proteolysis and muscle wasting by curcumin 3 complex in MAC16 colon tumour-bearing mice. Br. J. Nutr. 2009, 102, 967-975. [CrossRef]

199. Busquets, S.; Carbó, N.; Almendro, V.; Quiles, M.T.; López-Soriano, F.J.; Argilés, J.M. Curcumin, a natural product present in turmeric, decreases tumor growth but does not behave as an anticachectic compound in a rat model. Cancer Lett. 2001, 167, 33-38. [CrossRef]

200. Parsons, H.A.; Baracos, V.E.; Hong, D.S.; Abbruzzese, J.; Bruera, E.; Kurzrock, R. The effects of curcumin (diferuloylmethane) on body composition of patients with advanced pancreatic cancer. Oncotarget 2016, 7, 20293-20304. [CrossRef]

201. Bennett, B.T.; Mohamed, J.S.; Alway, S.E. Effects of resveratrol on the recovery of muscle mass following disuse in the plantaris muscle of aged rats. PLoS ONE 2013, 8, e83518. [CrossRef] [PubMed]

202. Charles, A.-L.; Meyer, A.; Dal-Ros, S.; Auger, C.; Keller, N.; Ramamoorthy, T.G.; Zoll, J.; Metzger, D.; Schini-Kerth, V.; Geny, B. Polyphenols prevent ageing-related impairment in skeletal muscle mitochondrial function through decreased reactive oxygen species production. Exp. Physiol. 2013, 98, 536-545. [CrossRef] [PubMed]

203. Annunziata, G.; Jimenez-García, M.; Tejada, S.; Moranta, D.; Arnone, A.; Ciampaglia, R.; Tenore, G.C.; Sureda, A.; Novellino, E.; Capó, X. Grape Polyphenols Ameliorate Muscle Decline Reducing Oxidative Stress and Oxidative Damage in Aged Rats. Nutrients 2020, 12, 1280. [CrossRef] [PubMed]

204. Wang, D.; Sun, H.; Song, G.; Yang, Y.; Zou, X.; Han, P.; Li, S. Resveratrol Improves Muscle Atrophy by Modulating Mitochondrial Quality Control in STZ-Induced Diabetic Mice. Mol. Nutr. Food Res. 2018, 62, e1700941. [CrossRef] [PubMed]

205. Dasgupta, A.; Shukla, S.K.; Vernucci, E.; King, R.J.; Abrego, J.; Mulder, S.E.; Mullen, N.J.; Graves, G.; Buettner, K.; Thakur, R.; et al. SIRT1-NOX4 signaling axis regulates cancer cachexia. J. Exp. Med. 2020, 217. [CrossRef] [PubMed]

206. Kim, O.Y.; Chung, J.Y.; Song, J. Effect of resveratrol on adipokines and myokines involved in fat browning: Perspectives in healthy weight against obesity. Pharmacol. Res. 2019, 148, 104411. [CrossRef]

207. Hendrickson, W.A.; Ward, K.B. Atomic models for the polypeptide backbones of myohemerythrin and hemerythrin. Biochem. Biophys. Res. Commun. 1975, 66, 1349-1356. [CrossRef]

208. Montesano, A.; Luzi, L.; Senesi, P.; Mazzocchi, N.; Terruzzi, I. Resveratrol promotes myogenesis and hypertrophy in murine myoblasts. J. Transl. Med. 2013, 11, 310. [CrossRef]

209. Haramizu, S.; Asano, S.; Butler, D.C.; Stanton, D.A.; Hajira, A.; Mohamed, J.S.; Alway, S.E. Dietary resveratrol confers apoptotic resistance to oxidative stress in myoblasts. J. Nutr. Biochem. 2017, 50, 103-115. [CrossRef]

210. Alamdari, N.; Aversa, Z.; Castillero, E.; Gurav, A.; Petkova, V.; Tizio, S.; Hasselgren, P.-O. Resveratrol prevents dexamethasone-induced expression of the muscle atrophy-related ubiquitin ligases atrogin-1 and MuRF1 in cultured myotubes through a SIRT1-dependent mechanism. Biochem. Biophys. Res. Commun. 2012, 417, 528-533. [CrossRef] 
211. Lee, D.; Goldberg, A.L. SIRT1 protein, by blocking the activities of transcription factors FoxO1 and FoxO3, inhibits muscle atrophy and promotes muscle growth. J. Biol. Chem. 2013, 288, 30515-30526. [CrossRef]

212. Shadfar, S.; Couch, M.E.; McKinney, K.A.; Weinstein, L.J.; Yin, X.; Rodríguez, J.E.; Guttridge, D.C.; Willis, M. Oral resveratrol therapy inhibits cancer-induced skeletal muscle and cardiac atrophy in vivo. Nutr. Cancer 2011, 63, 749-762. [CrossRef] [PubMed]

213. Busquets, S.; Fuster, G.; Ametller, E.; Olivan, M.; Figueras, M.; Costelli, P.; Carbó, N.; Argilés, J.M.; López-Soriano, F.J. Resveratrol does not ameliorate muscle wasting in different types of cancer cachexia models. Clin. Nutr. 2007, 26, 239-244. [CrossRef] [PubMed]

214. Mazibuko-Mbeje, S.E.; Dludla, P.V.; Nkambule, B.B.; Obonye, N.; Louw, J. Skeletal Muscle as a Therapeutic Target for Natural Products to Reverse Metabolic Syndrome. In Muscle Cell and Tissue - Current Status of Research Field; Sakuma, K., Ed.; InTechOpen: London, UK, 2018.

215. Otsuka, Y.; Egawa, K.; Kanzaki, N.; Izumo, T.; Rogi, T.; Shibata, H. Quercetin glycosides prevent dexamethasone-induced muscle atrophy in mice. Biochem. Biophys. Rep. 2019, 18, 100618. [CrossRef] [PubMed]

216. Chen, C.; Yang, J.-S.; Lu, C.-C.; Chiu, Y.-J.; Chen, H.-C.; Chung, M.-I.; Wu, Y.-T.; Chen, F.-A. Effect of Quercetin on Dexamethasone-Induced C2C12 Skeletal Muscle Cell Injury. Molecules 2020, 25, 3267. [CrossRef]

217. Velázquez, K.T.; Enos, R.T.; Narsale, A.A.; Puppa, M.J.; Davis, J.M.; Murphy, E.A.; Carson, J.A. Quercetin supplementation attenuates the progression of cancer cachexia in ApcMin/+ mice. J. Nutr. 2014, 144, 868-875. [CrossRef]

218. Davenport, C.; Hetzler, K.; Carson, J. Effects of Quercetin on Muscle Function during IL-6-induced Cancer Cachexia. FASEB J. 2015, 29, 825.6. [CrossRef]

219. Levolger, S.; van den Engel, S.; Ambagtsheer, G.; IJzermans, J.N.M.; de Bruin, R.W.F. Quercetin supplementation attenuates muscle wasting in cancer-associated cachexia in mice. Nutr. Healthy Aging 2020, 1-13. [CrossRef]

220. Camargo, C.A.; da Silva, M.E.F.; da Silva, R.A.; Justo, G.Z.; Gomes-Marcondes, M.C.C.; Aoyama, H. Inhibition of tumor growth by quercetin with increase of survival and prevention of cachexia in Walker 256 tumor-bearing rats. Biochem. Biophys. Res. Commun. 2011, 406, 638-642. [CrossRef]

221. Lu, J.-J.; Bao, J.-L.; Chen, X.-P.; Huang, M.; Wang, Y.-T. Alkaloids isolated from natural herbs as the anticancer agents. Evid Based Complement. Alternat. Med. 2012, 2012, 485042. [CrossRef]

222. Yong, J.; Wu, X.; Lu, C. Anticancer Advances of Matrine and Its Derivatives. Curr. Pharm. Des. 2015, 21, 3673-3680. [CrossRef] [PubMed]

223. Zhang, X.; Hou, G.; Liu, A.; Xu, H.; Guan, Y.; Wu, Y.; Deng, J.; Cao, X. Matrine inhibits the development and progression of ovarian cancer by repressing cancer associated phosphorylation signaling pathways. Cell Death Dis. 2019, 10, 770. [CrossRef] [PubMed]

224. Shi, J.; Han, X.; Wang, J.; Han, G.; Zhao, M.; Duan, X.; Mi, L.; Li, N.; Yin, X.; Shi, H.; et al. Matrine prevents the early development of hepatocellular carcinoma like lesions in rat liver. Exp. Ther. Med. 2019, 18, 2583-2591. [CrossRef] [PubMed]

225. Zhang, Y.; Zhang, H.; Yu, P.; Liu, Q.; Liu, K.; Duan, H.; Luan, G.; Yagasaki, K.; Zhang, G. Effects of matrine against the growth of human lung cancer and hepatoma cells as well as lung cancer cell migration. Cytotechnology 2009, 59, 191-200. [CrossRef] [PubMed]

226. Zhang, Y.; Wang, S.; Li, Y.; Xiao, Z.; Hu, Z.; Zhang, J. Sophocarpine and matrine inhibit the production of TNF-alpha and IL-6 in murine macrophages and prevent cachexia-related symptoms induced by colon 26 adenocarcinoma in mice. Int. Immunopharmacol. 2008, 8, 1767-1772. [CrossRef] [PubMed]

227. Chen, L.; Chen, L.; Wan, L.; Huo, Y.; Huang, J.; Li, J.; Lu, J.; Xin, B.; Yang, Q.; Guo, C. Matrine improves skeletal muscle atrophy by inhibiting E3 ubiquitin ligases and activating the Akt/mTOR/FoxO3 $\alpha$ signaling pathway in C2C12 myotubes and mice. Oncol. Rep. 2019, 42, 479-494. [CrossRef]

228. You, L.; Yang, C.; Du, Y.; Liu, Y.; Chen, G.; Sai, N.; Dong, X.; Yin, X.; Ni, J. Matrine Exerts Hepatotoxic Effects via the ROS-Dependent Mitochondrial Apoptosis Pathway and Inhibition of Nrf2-Mediated Antioxidant Response. Oxid. Med. Cell Longev. 2019, 2019, 1045345. [CrossRef]

229. Aghvami, M.; Ebrahimi, F.; Zarei, M.H.; Salimi, A.; Pourahmad Jaktaji, R.; Pourahmad, J. Matrine Induction of ROS Mediated Apoptosis in Human ALL B-lymphocytes Via Mitochondrial Targeting. Asian Pac. J. Cancer Prev. 2018, 19, 555-560. [CrossRef] 
230. Xu, B.; Xu, M.; Tian, Y.; Yu, Q.; Zhao, Y.; Chen, X.; Mi, P.; Cao, H.; Zhang, B.; Song, G.; et al. Matrine induces RIP3-dependent necroptosis in cholangiocarcinoma cells. Cell Death Discov. 2017, 3, 16096. [CrossRef]

231. Zhou, J.; Ma, W.; Wang, X.; Liu, H.; Miao, Y.; Wang, J.; Du, P.; Chen, Y.; Zhang, Y.; Liu, Z. Matrine Suppresses Reactive Oxygen Species (ROS)-Mediated MKKs/p38-Induced Inflammation in Oxidized Low-Density Lipoprotein (ox-LDL)-Stimulated Macrophages. Med. Sci. Monit. 2019, 25, 4130-4136. [CrossRef]

232. Mascali, J.J.; Cvietusa, P.; Negri, J.; Borish, L. Anti-inflammatory effects of theophylline: Modulation of cytokine production. Ann. Allergy Asthma Immunol. 1996, 77, 34-38. [CrossRef] [PubMed]

233. Olivan, M.; Springer, J.; Busquets, S.; Tschirner, A.; Figueras, M.; Toledo, M.; Fontes-Oliveira, C.; Genovese, M.I.; Ventura da Silva, P.; Sette, A.; et al. Theophylline is able to partially revert cachexia in tumour-bearing rats. Nutr. Metab. 2012, 9, 76. [CrossRef] [PubMed]

234. Caliceti, C.; Franco, P.; Spinozzi, S.; Roda, A.; Cicero, A.F.G. Berberine: New Insights from Pharmacological Aspects to Clinical Evidences in the Management of Metabolic Disorders. Curr. Med. Chem. 2016, 23, 1460-1476. [CrossRef] [PubMed]

235. Aggarwal, B.; Prasad, S.; Sung, B.; Krishnan, S.; Guha, S. Prevention and Treatment of Colorectal Cancer by Natural Agents From Mother Nature. Curr. Colorectal. Cancer Rep. 2013, 9, 37-56. [CrossRef]

236. Iizuka, N.; Miyamoto, K.; Hazama, S.; Yoshino, S.; Yoshimura, K.; Okita, K.; Fukumoto, T.; Yamamoto, S.; Tangoku, A.; Oka, M. Anticachectic effects of Coptidis rhizoma, an anti-inflammatory herb, on esophageal cancer cells that produce interleukin 6. Cancer Lett. 2000, 158, 35-41. [CrossRef]

237. Iizuka, N.; Hazama, S.; Yoshimura, K.; Yoshino, S.; Tangoku, A.; Miyamoto, K.; Okita, K.; Oka, M. Anticachectic effects of the natural herb Coptidis rhizoma and berberine on mice bearing colon 26/clone 20 adenocarcinoma. Int. J. Cancer 2002, 99, 286-291. [CrossRef]

238. Wu, Y.-Y.; Li, T.-M.; Zang, L.-Q.; Liu, B.; Wang, G.-X. Effects of berberine on tumor growth and intestinal permeability in HCT116 tumor-bearing mice using polyamines as targets. Biomed. Pharmacother. 2018, 107, 1447-1453. [CrossRef]

239. Costa, R.G.F.; Caro, P.L.; de Matos-Neto, E.M.; Lima, J.D.C.C.; Radloff, K.; Alves, M.J.; Camargo, R.G.; Pessoa, A.F.M.; Simoes, E.; Gama, P.; et al. Cancer cachexia induces morphological and inflammatory changes in the intestinal mucosa. J. Cachexia Sarcopenia Muscle 2019, 10, 1116-1127. [CrossRef]

240. Belgiovine, C.; Bello, E.; Liguori, M.; Craparotta, I.; Mannarino, L.; Paracchini, L.; Beltrame, L.; Marchini, S.; Galmarini, C.M.; Mantovani, A.; et al. Lurbinectedin reduces tumour-associated macrophages and the inflammatory tumour microenvironment in preclinical models. Br. J. Cancer 2017, 117, 628-638. [CrossRef]

241. Banihani, S.A. Tomato ( Solanum lycopersicum L.) and type 2 diabetes. Int. J. Food Prop. 2018, 21, 99-105. [CrossRef]

242. Dyle, M.C.; Ebert, S.M.; Cook, D.P.; Kunkel, S.D.; Fox, D.K.; Bongers, K.S.; Bullard, S.A.; Dierdorff, J.M.; Adams, C.M. Systems-based discovery of tomatidine as a natural small molecule inhibitor of skeletal muscle atrophy. J. Biol. Chem. 2014, 289, 14913-14924. [CrossRef] [PubMed]

243. Adams, C.M.; Ebert, S.M.; Dyle, M.C. Use of mRNA expression signatures to discover small molecule inhibitors of skeletal muscle atrophy. Curr. Opin. Clin. Nutr. Metab. Care 2015, 18, 263-268. [CrossRef] [PubMed]

244. Ghante, M.H.; Jamkhande, P.G. Role of Pentacyclic Triterpenoids in Chemoprevention and Anticancer Treatment: An Overview on Targets and Underling Mechanisms. J. Pharmacopuncture 2019, 22, 55-67. [CrossRef] [PubMed]

245. Shanmugam, M.K.; Dai, X.; Kumar, A.P.; Tan, B.K.H.; Sethi, G.; Bishayee, A. Ursolic acid in cancer prevention and treatment: Molecular targets, pharmacokinetics and clinical studies. Biochem. Pharmacol. 2013, 85, 1579-1587. [CrossRef] [PubMed]

246. Seo, D.Y.; Lee, S.R.; Heo, J.-W.; No, M.-H.; Rhee, B.D.; Ko, K.S.; Kwak, H.-B.; Han, J. Ursolic acid in health and disease. Korean J. Physiol. Pharmacol. 2018, 22, 235-248. [CrossRef] [PubMed]

247. Shen, S.; Zhang, Y.; Zhang, R.; Tu, X.; Gong, X. Ursolic acid induces autophagy in U87MG cells via ROS-dependent endoplasmic reticulum stress. Chem. Biol. Interact. 2014, 218, 28-41. [CrossRef]

248. Ebert, S.M.; Dyle, M.C.; Bullard, S.A.; Dierdorff, J.M.; Murry, D.J.; Fox, D.K.; Bongers, K.S.; Lira, V.A.; Meyerholz, D.K.; Talley, J.J.; et al. Identification and Small Molecule Inhibition of an Activating Transcription Factor 4 (ATF4)-dependent Pathway to Age-related Skeletal Muscle Weakness and Atrophy. J. Biol. Chem. 2015, 290, 25497-25511. [CrossRef] 
249. Yu, R.; Chen, J.-A.; Xu, J.; Cao, J.; Wang, Y.; Thomas, S.S.; Hu, Z. Suppression of muscle wasting by the plant-derived compound ursolic acid in a model of chronic kidney disease. J. Cachexia Sarcopenia Muscle 2017, 8, 327-341. [CrossRef]

250. Noh, K.K.; Chung, K.W.; Sung, B.; Kim, M.J.; Park, C.H.; Yoon, C.; Choi, J.S.; Kim, M.K.; Kim, C.M.; Kim, N.D.; et al. Loquat (Eriobotrya japonica) extract prevents dexamethasone-induced muscle atrophy by inhibiting the muscle degradation pathway in Sprague Dawley rats. Mol. Med. Rep. 2015, 12, 3607-3614. [CrossRef]

251. Kim, Y.-J.; Zhang, D.; Yang, D.-C. Biosynthesis and biotechnological production of ginsenosides. Biotechnol. Adv. 2015, 33, 717-735. [CrossRef]

252. Kim, J.H.; Yi, Y.-S.; Kim, M.-Y.; Cho, J.Y. Role of ginsenosides, the main active components of Panax ginseng, in inflammatory responses and diseases. J. Ginseng Res. 2017, 41, 435-443. [CrossRef] [PubMed]

253. Gillis, C.N. Panax ginseng pharmacology: A nitric oxide link? Biochem. Pharmacol. 1997, 54, 1-8. [CrossRef]

254. Mohanan, P.; Subramaniyam, S.; Mathiyalagan, R.; Yang, D.-C. Molecular signaling of ginsenosides Rb1, Rg1, and Rg3 and their mode of actions. J. Ginseng Res. 2018, 42, 123-132. [CrossRef] [PubMed]

255. Jeong, H.-J.; So, H.-K.; Jo, A.; Kim, H.-B.; Lee, S.-J.; Bae, G.-U.; Kang, J.-S. Ginsenoside Rg1 augments oxidative metabolism and anabolic response of skeletal muscle in mice. J. Ginseng Res. 2019, 43, 475-481. [CrossRef]

256. Lu, S.; Zhang, Y.; Li, H.; Zhang, J.; Ci, Y.; Han, M. Ginsenoside Rb1 can ameliorate the key inflammatory cytokines TNF- $\alpha$ and IL-6 in a cancer cachexia mouse model. BMC Complement. Med. Ther. 2020, 20, 11. [CrossRef]

257. Wang, Z.Y.; Nixon, D.W. Licorice and cancer. Nutr. Cancer 2001, 39, 1-11. [CrossRef]

258. Farooqui, A.; Khan, F.; Khan, I.; Ansari, I.A. Glycyrrhizin induces reactive oxygen species-dependent apoptosis and cell cycle arrest at G0/G1 in HPV18+ human cervical cancer HeLa cell line. Biomed. Pharmacother. 2018, 97, 752-764. [CrossRef]

259. Deng, Q.-P.; Wang, M.-J.; Zeng, X.; Chen, G.G.; Huang, R.-Y. Effects of Glycyrrhizin in a Mouse Model of Lung Adenocarcinoma. Cell. Physiol. Biochem. 2017, 41, 1383-1392. [CrossRef]

260. Yang, P.-S.; Kim, D.-H.; Lee, Y.J.; Lee, S.-E.; Kang, W.J.; Chang, H.-J.; Shin, J.-S. Glycyrrhizin, inhibitor of high mobility group box-1, attenuates monocrotaline-induced pulmonary hypertension and vascular remodeling in rats. Respir. Res. 2014, 15, 148. [CrossRef]

261. Ferrara, M.; Chialli, G.; Ferreira, L.M.; Ruggieri, E.; Careccia, G.; Preti, A.; Piccirillo, R.; Bianchi, M.E.; Sitia, G.; Venereau, E. Oxidation of HMGB1 Is a Dynamically Regulated Process in Physiological and Pathological Conditions. Front. Immunol. 2020, 11, 1122. [CrossRef]

262. Hurley, B.F.; Hanson, E.D.; Sheaff, A.K. Strength training as a countermeasure to aging muscle and chronic disease. Sports Med. 2011, 41, 289-306. [CrossRef] [PubMed]

263. Wernbom, M.; Augustsson, J.; Thomeé, R. The influence of frequency, intensity, volume and mode of strength training on whole muscle cross-sectional area in humans. Sports Med. 2007, 37, 225-264. [CrossRef] [PubMed]

264. Egan, B.; Zierath, J.R. Exercise metabolism and the molecular regulation of skeletal muscle adaptation. Cell Metab. 2013, 17, 162-184. [CrossRef] [PubMed]

265. Manson, J.E.; Hu, F.B.; Rich-Edwards, J.W.; Colditz, G.A.; Stampfer, M.J.; Willett, W.C.; Speizer, F.E.; Hennekens, C.H. A prospective study of walking as compared with vigorous exercise in the prevention of coronary heart disease in women. N. Engl. J. Med. 1999, 341, 650-658. [CrossRef]

266. McPhee, J.S.; French, D.P.; Jackson, D.; Nazroo, J.; Pendleton, N.; Degens, H. Physical activity in older age: Perspectives for healthy ageing and frailty. Biogerontology 2016, 17, 567-580. [CrossRef]

267. Padrão, A.I.; Figueira, A.C.C.; Faustino-Rocha, A.I.; Gama, A.; Loureiro, M.M.; Neuparth, M.J.; Moreira-Gonçalves, D.; Vitorino, R.; Amado, F.; Santos, L.L.; et al. Long-term exercise training prevents mammary tumorigenesis-induced muscle wasting in rats through the regulation of TWEAK signalling. Acta Physiol. 2017, 219, 803-813. [CrossRef]

268. Petersen, A.M.W.; Pedersen, B.K. The anti-inflammatory effect of exercise. J. Appl. Physiol. 2005, 98, 1154-1162. [CrossRef]

269. Pedersen, B.K.; Febbraio, M.A. Muscle as an endocrine organ: Focus on muscle-derived interleukin-6. Physiol. Rev. 2008, 88, 1379-1406. [CrossRef]

270. Burini, R.C.; Anderson, E.; Durstine, J.L.; Carson, J.A. Inflammation, physical activity, and chronic disease: An evolutionary perspective. Sports Med. Health Sci. 2020, 2, 1-6. [CrossRef]

271. Daou, H.N. Exercise as an anti-inflammatory therapy for cancer cachexia: A focus on interleukin-6 regulation. Am. J. Physiol. Regul. Integr. Comp. Physiol. 2020, 318, R296-R310. [CrossRef] 
272. Piccirillo, R. Exercise-Induced Myokines With Therapeutic Potential for Muscle Wasting. Front. Physiol. 2019, 10, 287. [CrossRef] [PubMed]

273. Demontis, F.; Piccirillo, R.; Goldberg, A.L.; Perrimon, N. The influence of skeletal muscle on systemic aging and lifespan. Aging Cell 2013, 12, 943-949. [CrossRef] [PubMed]

274. McPherron, A.C.; Lawler, A.M.; Lee, S.J. Regulation of skeletal muscle mass in mice by a new TGF-beta superfamily member. Nature 1997, 387, 83-90. [CrossRef] [PubMed]

275. Hittel, D.S.; Axelson, M.; Sarna, N.; Shearer, J.; Huffman, K.M.; Kraus, W.E. Myostatin decreases with aerobic exercise and associates with insulin resistance. Med. Sci. Sports Exerc. 2010, 42, 2023-2029. [CrossRef]

276. Smith, R.C.; Lin, B.K. Myostatin inhibitors as therapies for muscle wasting associated with cancer and other disorders. Curr. Opin. Support. Palliat. Care 2013, 7, 352-360. [CrossRef]

277. Cipriano, S.C.; Chen, L.; Kumar, T.R.; Matzuk, M.M. Follistatin is a modulator of gonadal tumor progression and the activin-induced wasting syndrome in inhibin-deficient mice. Endocrinology 2000, 141, 2319-2327. [CrossRef]

278. Gould, D.W.; Lahart, I.; Carmichael, A.R.; Koutedakis, Y.; Metsios, G.S. Cancer cachexia prevention via physical exercise: Molecular mechanisms. J. Cachexia Sarcopenia Muscle 2013, 4, 111-124. [CrossRef]

279. Stefanetti, R.J.; Lamon, S.; Wallace, M.; Vendelbo, M.H.; Russell, A.P.; Vissing, K. Regulation of ubiquitin proteasome pathway molecular markers in response to endurance and resistance exercise and training. Pflugers Arch. 2015, 467, 1523-1537. [CrossRef]

280. Yang, Y.; Jemiolo, B.; Trappe, S. Proteolytic mRNA expression in response to acute resistance exercise in human single skeletal muscle fibers. J. Appl. Physiol. 2006, 101, 1442-1450. [CrossRef]

281. Harber, M.P.; Crane, J.D.; Dickinson, J.M.; Jemiolo, B.; Raue, U.; Trappe, T.A.; Trappe, S.W. Protein synthesis and the expression of growth-related genes are altered by running in human vastus lateralis and soleus muscles. Am. J. Physiol. Regul. Integr. Comp. Physiol. 2009, 296, R708-R714. [CrossRef]

282. Stefanetti, R.J.; Lamon, S.; Rahbek, S.K.; Farup, J.; Zacharewicz, E.; Wallace, M.A.; Vendelbo, M.H.; Russell, A.P.; Vissing, K. Influence of divergent exercise contraction mode and whey protein supplementation on atrogin-1, MuRF1, and FOXO1/3A in human skeletal muscle. J. Appl. Physiol. 2014, 116, 1491-1502. [CrossRef] [PubMed]

283. Alves, C.R.R.; das Neves, W.; Tobias, G.C.; de Almeida, N.R.; Barreto, R.F.; Melo, C.M.; de G. Carneiro, C.; Garcez, A.T.; de P. Faria, D.; Chammas, R.; et al. High-intensity interval training slows down tumor progression in mice bearing Lewis lung carcinoma. JCSM Rapid Commun. 2018, 1, 1-10. [CrossRef]

284. Sato, R.; Ito, K.; Oyama, C.; Ebihara, T.; Kohzuki, M.; and, S.E. Effect Of Exercise Training On Cancer Cachexia In Lewis Lung Carcinoma (LLC) Mouse Model. In C29. MUSCLES, EXERCISE ASSESSMENT, AND REHABILITATION; ATSJournal: New York, NY, USA, 2014; p. A4163.

285. Jee, H.; Chang, J.-E.; Yang, E.J. Positive Prehabilitative Effect of Intense Treadmill Exercise for Ameliorating Cancer Cachexia Symptoms in a Mouse Model. J. Cancer 2016, 7, 2378-2387. [CrossRef] [PubMed]

286. Puppa, M.J.; White, J.P.; Velázquez, K.T.; Baltgalvis, K.A.; Sato, S.; Baynes, J.W.; Carson, J.A. The effect of exercise on IL-6-induced cachexia in the Apc ( Min/+) mouse. J. Cachexia Sarcopenia Muscle 2012, 3, 117-137. [CrossRef] [PubMed]

287. Tanaka, M.; Sugimoto, K.; Fujimoto, T.; Xie, K.; Takahashi, T.; Akasaka, H.; Kurinami, H.; Yasunobe, Y.; Matsumoto, T.; Fujino, H.; et al. Preventive effects of low-intensity exercise on cancer cachexia-induced muscle atrophy. FASEB J. 2019, 33, 7852-7862. [CrossRef]

288. Patel, D.I.; Abuchowski, K.; Sheikh, B.; Rivas, P.; Musi, N.; Kumar, A.P. Exercise preserves muscle mass and force in a prostate cancer mouse model. Eur. J. Transl. Myol. 2019, 29, 8520. [CrossRef]

289. Pigna, E.; Berardi, E.; Aulino, P.; Rizzuto, E.; Zampieri, S.; Carraro, U.; Kern, H.; Merigliano, S.; Gruppo, M.; Mericskay, M.; et al. Aerobic Exercise and Pharmacological Treatments Counteract Cachexia by Modulating Autophagy in Colon Cancer. Sci. Rep. 2016, 6. [CrossRef]

290. Penna, F.; Costamagna, D.; Pin, F.; Camperi, A.; Fanzani, A.; Chiarpotto, E.M.; Cavallini, G.; Bonelli, G.; Baccino, F.M.; Costelli, P. Autophagic degradation contributes to muscle wasting in cancer cachexia. Am. J. Pathol. 2013, 182, 1367-1378. [CrossRef]

291. Kim, J.; Yang, G.; Kim, Y.; Kim, J.; Ha, J. AMPK activators: Mechanisms of action and physiological activities. Exp. Mol. Med. 2016, 48, e224. [CrossRef]

292. Ballou, L.M.; Lin, R.Z. Rapamycin and mTOR kinase inhibitors. J. Chem. Biol. 2008, 1, 27-36. [CrossRef] 
293. Molinari, F.; Pin, F.; Gorini, S.; Chiandotto, S.; Pontecorvo, L.; Penna, F.; Rizzuto, E.; Pisu, S.; Musarò, A.; Costelli, P.; et al. The mitochondrial metabolic reprogramming agent trimetazidine as an "exercise mimetic" in cachectic C26-bearing mice. J. Cachexia Sarcopenia Muscle 2017, 8, 954-973. [CrossRef] [PubMed]

294. Coletti, D.; Aulino, P.; Pigna, E.; Barteri, F.; Moresi, V.; Annibali, D.; Adamo, S.; Berardi, E. Spontaneous Physical Activity Downregulates Pax7 in Cancer Cachexia. Stem Cells Int. 2016, 2016, 6729268. [CrossRef] [PubMed]

295. Ranjbar, K.; Ballarò, R.; Bover, Q.; Pin, F.; Beltrà, M.; Penna, F.; Costelli, P. Combined Exercise Training Positively Affects Muscle Wasting in Tumor-Bearing Mice. Med. Sci. Sports Exerc. 2019, 51, 1387-1395. [CrossRef] [PubMed]

296. White, J.P.; Puppa, M.J.; Sato, S.; Gao, S.; Price, R.L.; Baynes, J.W.; Kostek, M.C.; Matesic, L.E.; Carson, J.A. IL-6 regulation on skeletal muscle mitochondrial remodeling during cancer cachexia in the ApcMin/+ mouse. Skelet. Muscle 2012, 2, 14. [CrossRef]

297. Padilha, C.S.; Borges, F.H.; Costa Mendes da Silva, L.E.; Frajacomo, F.T.T.; Jordao, A.A.; Duarte, J.A.; Cecchini, R.; Guarnier, F.A.; Deminice, R. Resistance exercise attenuates skeletal muscle oxidative stress, systemic pro-inflammatory state, and cachexia in Walker-256 tumor-bearing rats. Appl. Physiol. Nutr. Metab. 2017, 42, 916-923. [CrossRef] [PubMed]

298. Khamoui, A.V.; Park, B.-S.; Kim, D.-H.; Yeh, M.-C.; Oh, S.-L.; Elam, M.L.; Jo, E.; Arjmandi, B.H.; Salazar, G.; Grant, S.C.; et al. Aerobic and resistance training dependent skeletal muscle plasticity in the colon-26 murine model of cancer cachexia. Metab. Clin. Exp. 2016, 65, 685-698. [CrossRef]

299. Assi, M.; Rébillard, A. The Janus-Faced Role of Antioxidants in Cancer Cachexia: New Insights on the Established Concepts. Oxid. Med. Cell Longev. 2016, 2016, 9579868. [CrossRef]

300. Gomez-Cabrera, M.-C.; Domenech, E.; Viña, J. Moderate exercise is an antioxidant: Upregulation of antioxidant genes by training. Free Radic. Biol. Med. 2008, 44, 126-131. [CrossRef]

301. Penna, F.; Ballarò, R.; Costelli, P. The Redox Balance: A Target for Interventions against Muscle Wasting in Cancer Cachexia? Antioxid. Redox Signal. 2020, 33, 542-558. [CrossRef]

302. Lira, F.S.; de M M Antunes, B.; Seelaender, M.; Rosa Neto, J.C. The therapeutic potential of exercise to treat cachexia. Curr. Opin. Support. Palliat. Care 2015, 9, 317-324. [CrossRef]

303. Lira, F.S.; Neto, J.C.R.; Seelaender, M. Exercise training as treatment in cancer cachexia. Appl. Physiol. Nutr. Metab. 2014, 39, 679-686. [CrossRef] [PubMed]

304. Repka, C.P.; Hayward, R. Effects of an Exercise Intervention on Cancer-Related Fatigue and Its Relationship to Markers of Oxidative Stress. Integr. Cancer Ther. 2018, 17, 503-510. [CrossRef] [PubMed]

305. Repka, C.P.; Hayward, R. Oxidative Stress and Fitness Changes in Cancer Patients after Exercise Training. Med. Sci. Sports Exerc. 2016, 48, 607-614. [CrossRef]

306. Wiskemann, J.; Clauss, D.; Tjaden, C.; Hackert, T.; Schneider, L.; Ulrich, C.M.; Steindorf, K. Progressive Resistance Training to Impact Physical Fitness and Body Weight in Pancreatic Cancer Patients: A Randomized Controlled Trial. Pancreas 2019, 48, 257-266. [CrossRef] [PubMed]

307. Segal, R.J.; Reid, R.D.; Courneya, K.S.; Sigal, R.J.; Kenny, G.P.; Prud'Homme, D.G.; Malone, S.C.; Wells, G.A.; Scott, C.G.; Slovinec D'Angelo, M.E. Randomized controlled trial of resistance or aerobic exercise in men receiving radiation therapy for prostate cancer. J. Clin. Oncol. 2009, 27, 344-351. [CrossRef]

308. Courneya, K.S.; Segal, R.J.; Mackey, J.R.; Gelmon, K.; Reid, R.D.; Friedenreich, C.M.; Ladha, A.B.; Proulx, C.; Vallance, J.K.H.; Lane, K.; et al. Effects of aerobic and resistance exercise in breast cancer patients receiving adjuvant chemotherapy: A multicenter randomized controlled trial. J. Clin. Oncol. 2007, 25, 4396-4404. [CrossRef]

309. Grote, M.; Maihöfer, C.; Weigl, M.; Davies-Knorr, P.; Belka, C. Progressive resistance training in cachectic head and neck cancer patients undergoing radiotherapy: A randomized controlled pilot feasibility trial. Radiat. Oncol. 2018, 13, 215. [CrossRef]

310. Lønbro, S.; Dalgas, U.; Primdahl, H.; Johansen, J.; Nielsen, J.L.; Aagaard, P.; Hermann, A.P.; Overgaard, J.; Overgaard, K. Progressive resistance training rebuilds lean body mass in head and neck cancer patients after radiotherapy-results from the randomized DAHANCA 25B trial. Radiother. Oncol. 2013, 108, 314-319. [CrossRef]

311. Christensen, J.F.; Jones, L.W.; Andersen, J.L.; Daugaard, G.; Rorth, M.; Hojman, P. Muscle dysfunction in cancer patients. Ann. Oncol. 2014, 25, 947-958. [CrossRef] 
312. Qaisar, R.; Bhaskaran, S.; Van Remmen, H. Muscle fiber type diversification during exercise and regeneration. Free Radic. Biol. Med. 2016, 98, 56-67. [CrossRef]

313. Miura, S.; Naito, T.; Mitsunaga, S.; Omae, K.; Mori, K.; Inano, T.; Yamaguchi, T.; Tatematsu, N.; Okayama, T.; Morikawa, A.; et al. A randomized phase II study of nutritional and exercise treatment for elderly patients with advanced non-small cell lung or pancreatic cancer: The NEXTAC-TWO study protocol. BMC Cancer 2019, 19, 528. [CrossRef] [PubMed]

314. Vanhoutte, G.; van de Wiel, M.; Wouters, K.; Sels, M.; Bartolomeeussen, L.; De Keersmaecker, S.; Verschueren, C.; De Vroey, V.; De Wilde, A.; Smits, E.; et al. Cachexia in cancer: What is in the definition? BMJ Open Gastroenterol. 2016, 3, e000097. [CrossRef] [PubMed]

315. Bang, H.S.; Seo, D.Y.; Chung, Y.M.; Oh, K.-M.; Park, J.J.; Arturo, F.; Jeong, S.-H.; Kim, N.; Han, J. Ursolic Acid-induced elevation of serum irisin augments muscle strength during resistance training in men. Korean J. Physiol. Pharmacol. 2014, 18, 441-446. [CrossRef] [PubMed]

316. Gammone, M.A.; Riccioni, G.; Parrinello, G.; D'Orazio, N. Omega-3 Polyunsaturated Fatty Acids: Benefits and Endpoints in Sport. Nutrients 2018, 11, 46. [CrossRef] [PubMed]

317. Deane, C.S.; Wilkinson, D.J.; Phillips, B.E.; Smith, K.; Etheridge, T.; Atherton, P.J. "Nutraceuticals" in relation to human skeletal muscle and exercise. Am. J. Physiol. Endocrinol. Metab. 2017, 312, E282-E299. [CrossRef]

318. de Carvalho, F.G.; Fisher, M.G.; Thornley, T.T.; Roemer, K.; Pritchett, R.; de Freitas, E.C.; Pritchett, K. Cocoa flavanol effects on markers of oxidative stress and recovery after muscle damage protocol in elite rugby players. Nutrition 2019, 62, 47-51. [CrossRef]

319. Ray Hamidie, R.D.; Yamada, T.; Ishizawa, R.; Saito, Y.; Masuda, K. Curcumin treatment enhances the effect of exercise on mitochondrial biogenesis in skeletal muscle by increasing cAMP levels. Metab. Clin. Exp. 2015, 64, 1334-1347. [CrossRef]

320. Yu, S.-H.; Huang, H.-Y.; Korivi, M.; Hsu, M.-F.; Huang, C.-Y.; Hou, C.-W.; Chen, C.-Y.; Kao, C.-L.; Lee, R.-P.; Lee, S.-D.; et al. Oral Rg1 supplementation strengthens antioxidant defense system against exercise-induced oxidative stress in rat skeletal muscles. J. Int. Soc. Sports Nutr. 2012, 9, 23. [CrossRef]

321. Jeong, J.-W.; Shim, J.-J.; Choi, I.-D.; Kim, S.-H.; Ra, J.; Ku, H.K.; Lee, D.E.; Kim, T.-Y.; Jeung, W.; Lee, J.-H.; et al. Apple Pomace Extract Improves Endurance in Exercise Performance by Increasing Strength and Weight of Skeletal Muscle. J. Med. Food 2015, 18, 1380-1386. [CrossRef]

322. Simioni, C.; Zauli, G.; Martelli, A.M.; Vitale, M.; Sacchetti, G.; Gonelli, A.; Neri, L.M. Oxidative stress: Role of physical exercise and antioxidant nutraceuticals in adulthood and aging. Oncotarget 2018, 9, 17181-17198. [CrossRef]

323. Penna, F.; Busquets, S.; Pin, F.; Toledo, M.; Baccino, F.M.; López-Soriano, F.J.; Costelli, P.; Argilés, J.M. Combined approach to counteract experimental cancer cachexia: Eicosapentaenoic acid and training exercise. J. Cachexia Sarcopenia Muscle 2011, 2, 95-104. [CrossRef] [PubMed]

324. Asadmanesh, E.; Koushki Jahromi, M.; Daryanoosh, F.; Neamati, J.; Samadi, M. Resveratrol Supplement Could Reverse the Effect of Resistance Training on Muscular eMHC and PAX7 in BALB/C Mice Bearing CT-26 Tumor. Rep. Health Care 2019, 5, 27-34.

325. Solheim, T.S.; Laird, B.J.A.; Balstad, T.R.; Stene, G.B.; Bye, A.; Johns, N.; Pettersen, C.H.; Fallon, M.; Fayers, P.; Fearon, K.; et al. A randomized phase II feasibility trial of a multimodal intervention for the management of cachexia in lung and pancreatic cancer. J. Cachexia Sarcopenia Muscle 2017, 8, 778-788. [CrossRef] [PubMed]

326. Solheim, T.S.; Laird, B.J.A.; Balstad, T.R.; Bye, A.; Stene, G.; Baracos, V.; Strasser, F.; Griffiths, G.; Maddocks, M.; Fallon, M.; et al. Cancer cachexia: Rationale for the MENAC (Multimodal-Exercise, Nutrition and Anti-inflammatory medication for Cachexia) trial. BMJ Support. Palliat. Care 2018, 8, 258-265. [CrossRef] [PubMed]

327. Tobberup, R.; Carus, A.; Rasmussen, H.H.; Falkmer, U.G.; Jorgensen, M.G.; Schmidt, E.B.; Jensen, N.A.; Mark, E.B.; Delekta, A.M.; Antoniussen, C.S.; et al. Feasibility of a multimodal intervention on malnutrition in patients with lung cancer during primary anti-neoplastic treatment. Clin. Nutr. 2020. [CrossRef] [PubMed]

328. Hopkinson, J.B. Psychosocial impact of cancer cachexia. J. Cachexia Sarcopenia Muscle 2014, 5, 89-94. [CrossRef]

329. Naito, T.; Mitsunaga, S.; Miura, S.; Tatematsu, N.; Inano, T.; Mouri, T.; Tsuji, T.; Higashiguchi, T.; Inui, A.; Okayama, T.; et al. Feasibility of early multimodal interventions for elderly patients with advanced pancreatic and non-small-cell lung cancer. J. Cachexia Sarcopenia Muscle 2019, 10, 73-83. [CrossRef] 
330. Schink, K.; Herrmann, H.J.; Schwappacher, R.; Meyer, J.; Orlemann, T.; Waldmann, E.; Wullich, B.; Kahlmeyer, A.; Fietkau, R.; Lubgan, D.; et al. Effects of whole-body electromyostimulation combined with individualized nutritional support on body composition in patients with advanced cancer: A controlled pilot trial. BMC Cancer 2018, 18, 886. [CrossRef]

331. Toden, S.; Goel, A. The Holy Grail of Curcumin and its Efficacy in Various Diseases: Is Bioavailability Truly a Big Concern? J. Restor. Med. 2017, 6, 27-36. [CrossRef]

332. Klein, G.L.; Petschow, B.W.; Shaw, A.L.; Weaver, E. Gut barrier dysfunction and microbial translocation in cancer cachexia: A new therapeutic target. Curr. Opin. Support. Palliat. Care 2013, 7, 361-367. [CrossRef]

333. Il'yasova, D.; Scarbrough, P.; Spasojevic, I. Urinary biomarkers of oxidative status. Clin. Chim. Acta 2012, 413, 1446-1453. [CrossRef] [PubMed]

334. Merry, T.L.; Ristow, M. Do antioxidant supplements interfere with skeletal muscle adaptation to exercise training? J. Physiol. 2016, 594, 5135-5147. [CrossRef] [PubMed]

Publisher's Note: MDPI stays neutral with regard to jurisdictional claims in published maps and institutional affiliations.

(C) 2020 by the authors. Licensee MDPI, Basel, Switzerland. This article is an open access article distributed under the terms and conditions of the Creative Commons Attribution (CC BY) license (http://creativecommons.org/licenses/by/4.0/). 